\title{
Tritium Oxidation and Exchange: Preliminary Studies
}

\author{
J. E. Phillips \\ C. E. Easterly
}

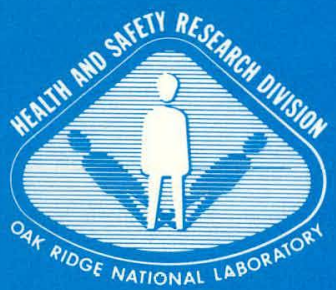




\section{DISCLAIMER}

This report was prepared as an account of work sponsored by an agency of the United States Government. Neither the United States Government nor any agency Thereof, nor any of their employees, makes any warranty, express or implied, or assumes any legal liability or responsibility for the accuracy, completeness, or usefulness of any information, apparatus, product, or process disclosed, or represents that its use would not infringe privately owned rights. Reference herein to any specific commercial product, process, or service by trade name, trademark, manufacturer, or otherwise does not necessarily constitute or imply its endorsement, recommendation, or favoring by the United States Government or any agency thereof. The views and opinions of authors expressed herein do not necessarily state or reflect those of the United States Government or any agency thereof. 


\section{DISCLAIMER}

Portions of this document may be illegible in electronic image products. Images are produced from the best available original document. 


\begin{tabular}{c}
\hline Printed in the United States of America. Available from \\
National Technical Information Service \\
U.S. Department of Commerce \\
5285 Port Royal Road, Spring field, Virginia 22161 \\
Price: Printed Copy $\$ 6.00 ;$ Microfiche $\$ 3.00$ \\
5.25
\end{tabular}

This report was prepared as an account of work sponsored by an agency of the United States Government. Neither the United States Government nor any agency thereof, nor any of their employees, contractors, subcontractors, or their employees, makes any warranty, express or implied, nor assumes any legal liability or responsibility for any third party's use or the results of such use of any information, apparatus, product or process disclosed in this report, nor represents that its use by such third party would not infringe privately owned rights. 
ORNL/TM-5963

Dist. Category UC-20,-20e

Contract No. W-7405-eng-26

HEALTH AND SAFETY RESEARCH DIVISION

Fusion Technology Group

TRITIUM OXIDATION AND EXCHANGE: PRELIMINARY STUDIES

J. E. Phillips

C. E. Easterly

Date Published - May, 1978

Submitted by J. E. Phillips

to the Graduate School of the University of North Carolina

in partial fulfillment of the requirements for the degree

of Master of Science in Public Health.

NOTICE This document contairis information of a preliminary nature. It is subject to revision or correction and therefore does not represent a final report.
NAK RIDGF, NATIONAL LABORATORY
Oak Ridge, Tennessee 37830 operated by
UNION CARBIDE CORPORATION for the
DEPARTMENT OF ENERGY

This repor NOTIGE sponsored by the prepared as an account of work United States nor the United Government. Neither the Energy, nor any of United States Department of contractors, any of their employees, nor any of their any warra, subcontractors, or their employees, makes liability or rexpess or implied, or assumes any legal or useful responsibily for the accurecy, completeness proces uness of any information, apparatus product process disclused, of represents that its use would not
infringe privately owned rights. 
THIS PAGE

\section{WAS INTENTIONALLY LEFT BLANK}


TABLE OF CONTENTS

SECTION

PAGE

LIST OF FIGURES . . . . . . . . . . . . . . . . . . . v v

LIST OF TABLES ......................... . . .

ACKNOWLEDGEMENTS . . . . . . . . . . . . . . . . . . . . ix

ABSTRACT .......................... . . . . xi

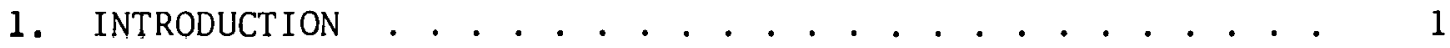

2. RADIOLOGICAL HAZARDS OF TRITIUN AND TRITIUM OXIDE . . . . . 2

2.1. Inhalation . . . . . . . . . . . . . . . . . . . . 2

2.2. Percutaneous Absorption from Air . . . . . . . . . . 3

2.3. Percutaneous Absorption from a Metal Surface . . . . 5

2.4. Conclusions Regarding Radiological Hazards . . . . . 7

3. SOURCES OF TRITIUN . . . . . . . . . . . . . . . . . 9

3.1. Natural Production . . . . . . . . . . . . 9

3.2. Nuclear Detonations . . . . . . . . . . . . 9

3.3. Fission Reactors ................ . 10

3.4. Fuel Reprocessing . . . . . . . . . . . . . 12

3.5. Tritium Production Facilities... . . . . . . . 12

3.6. Thermonuclear Reactors . . . . . . . . . . . . 13

3.7. Conclusions Concerning the Sources of Tritium . . . . 13

4. PREVIOUS STUDIES . . . . . . . . . . . . . . . 15

4.1. HT $\rightarrow$ HTO Conversion in Dry Gas Mixtures . . . . . . . 15

High initial tritium concentrations . . . . . . . . 19

Lower initial tritium concentrations . . . . . . . 19

4.2. HT $\rightarrow$ HTO Conversion in Moist Gas Mixtures . . . . . 23

4.3. Surface and. Pressure Effects . . . . . . . . . . . 25

4.4. Conclusions from Previous Studies . . . . . . . . 26

5. EXPERIMENTAL METHODS . . . . . . . . . . . . . . . 28

5.1. Apparatus . . . . . . . . . . . . . . . 28

Tritiun supply system... . . . . . . . . 28

Vacuum system................. . 30

Reaction flasks................ 32

Bubbler system . . . . . . . . . . . . . . 32

Calibration of flow gauges . . . . . . . . . . 35

Determination of furnace temperature . . . . . . 36 
5.2. Procedure . . . . . . . . . . . . . . . 36

Flask preparation procedure . . . . . . . . 36

Flask preparation for the soil run . . . . . . 37

Sampling procedure ... . . . . . . . . 38

Cleaning procedures . . . . . . . . . . . . 38

5.3. Experimental Results . . . . . . . . . . . . . 39

Data . . . . . . . . . . . . . . . . . . 39

Determination of the initial tritium

concentration . . . . . . . . . . . . . . 40

Determination of the reaction rate constant. . . 44 .

Discussion .. . . . . . . . . . . . . . 47

Tritium oxidation in a dry air atmosphere. . . . 49

liritiun oxidation in dry aır atmosphere in presence of soil . . . . . . . . . . . . 51

Conversion of tritium to tritium oxide in

a moist air environment. . . . . . . . . . 51

6. RECOMMENDATIONS AND CONCLUSIONS . . . . . . . . . . . 54

6.1. Recommendations ................. . 54

6.2. Summary and Conclusions . . . . . . . . . . . . . 56

REFERENCES . . . . . . . . . . . . . . . . . . . 57 
LIST OF FIGURES

FIGURE

PAGE

4.1.1. Dependence of the reaction rate on the protium mole fraction. . . . . . . . . . . . . . . . . . . .

4.1.2. Initial reaction rate corrected for the protium mole fraction of the hydrogen gas as a function of the initial tritium concentration ..............

4.1.3. First order reaction rate constant as a function

of initial tritium concentration . . . . . . . . . . . .

4.2.1. The rate of formation of HTO by the exchange of a tritium atom with a protium atom in a water molecule as a function of initial tritium concentration . . . . . .

5.1.1. Vacuum system for evacuating the reaction flasks and backfilling the flask with tritium gas . . . . . . .

5.1.2. Reaction flask with sampling port . . . . . . . . . . 33

5.1.3. Bubbler system for sampling reaction flasks . . . . . . . 34

5.3.1. First order reaction rate constant as a function of the initial tritium concentration . . . . . . . . . . 
THIS PAGE

\section{WAS INTENTIONALLY LEFT BLANK}




\section{LIST OF TABLES}

\section{TABLE}

PAGE

5.3.1. Data for dry air atmosphere . . . . . . . . . . . . 41

5.3.2. Data for dry air atmosphere and soil . . . . . . . . . 42

5.3.3. Data for moist air atmosphere . . . . . . . . . . . 43

5.3.4. Reaction rate constants . . . . . . . . . . . . 47 
THIS PAGE

\section{WAS INTENTIONALLY LEFT BLANK}




\section{ACKNOWLEDGEMENTS}

Gratitude is expressed by J. E. Phillips to Oak Ridge Associated Universities and to Oak Ridge National Laboratory, operated by Union Carbide Corporation for the Department of Energy, for support in the investigations. 
THIS PAGE

\section{WAS INTENTIONALLY LEFT BLANK}


ABSTRACT

TRITIUM OXIDATION AND EXCHANGE: PRELIMINARY STUDIES

J. E. Phillips and C. E. Easterly

The radiological hazard resulting from an exposure to either tritium oxide or tritium gas is discussed and the factors contributing to the hazard are presented. From the discussion it appears that an exposure to tritium oxide vapor is $10^{4}$ to $10^{5}$ times more hazardous than exposure to tritium gas. Present and future sources of tritium are briefly considered and indicate that most of the tritium has been and is being released as tritium oxide. The likelihood of gaseous releases, however, is expected to increase in the future, calling to task the present general release assumption that $100 \%$ of all tritium released is as oxide. Accurate evaluation of the hazards from a gaseous release will require a knowledge of the conversion rate of tritium gas to tritium oxide. An experiment for determining the conversion rate of tritium gas to tritium oxide is presented along with some preliminary data. The conversion rates obtained for low initial concentrations $\left(10^{-4}\right.$ to $\left.10^{-1} \mathrm{mCi} / \mathrm{ml}\right)$ indicate the conversion may proceed more rapidly than would be expected from an extrapolation of previous data taken at higher concentrations $\left(10^{-1}\right.$ to $\left.10^{2} \mathrm{mCi} / \mathrm{ml}\right)$. 


\section{INTRODUCTION}

In the past, interest in tritium exposure has primarily focused on exposure to tritium oxide although large quantities of tritium gas have, on occasion, been accidentally released from tritium production and handling facilities within the United States. While no significant exposures from these releases have been reported, the risk of exposure to significant levels of tritium gas will increase if present trends continue in the development of fusion reactors that are fueled with tritium gas. For this reason, a more accurate assessment of the radiological implications of exposure to tritium gas is desirable.

The conversion rate of tritium gas to tritium oxide must be known before the radiological implication of an exposure to the gas can be determined. This is due to the more hazardous nature of the oxide form. Present knowledge of the conversion rate is limited to relatively high tritium gas concentrations in the following gas mixtures: (1) pure oxygen; (2) oxygen and water vapor; (3) dry air; (4) dry air and water vapor; (5) oxygen, hydrogen, and inert gas; and (6) oxygen, hydrogen, inert gas, and water vapor. Some of the conclusions from these studies are conflicting, and the influence of atmospheric constituents on the reaction rate has not been studied.

The objectives of this paper are: (1) to discuss the relative radiological hazards of tritium and tritium oxide; (2) to delineate the sources of tritium, quantify their releases, and establish the chemical form of the releases; (3) to present previous findings of the conversion rate of tritium gas to tritium oxide; (4) to present the preliminary results of a tritium conversion rate experiment; and (b) to make recommendations for future experiments. 


\section{RADIOLOGICAL HAZARDS OF TRITIUM AND TRITIUM OXIDE}

Both the physical properties and chemical form of tritium determine the hazard from an exposure to tritium. Regardless of its chemical form, tritium decays with a half-life of 12.3 years by emitting a beta particle having a maximum energy of $18 \mathrm{keV}$ and an average energy of 5.7 keV. (1) These low energy beta particles do not present an external exposure hazard (the beta particles do not penetrate the dead, outer layer of skin); however, they present a potential hazard when emitted within the body where live tissue is exposed. Therefore, the hazard depends on the uptake and retention of the tritium which, in turn, depends on the chemical form of the tritium. For this reason the chemical form and the uptake rate must be known before an accurate assessment of the hazard from an exposure to tritium can be made. The more common chemical forms that occur in the environment and are available for uptake are tritium as tritium oxide vapor or liquid (HTO or $\mathrm{T}_{2} \mathrm{O}$ ), tritium as tritium gas ( $\mathrm{HT}$ or $\mathrm{T}_{2}$ ) or tritiun as an organic

compound where one or more protium atoms are replaced by the tritium. $(2,3)$

Inhalation and percutaneous absorption are the two routes by which tritium oxide vapor or tritium gas may be incorporated into the budy.

\subsection{Inhalation}

There is a large uptake of HTO vapor during an exposure through inhalation. Human subjects inhaling air contaminated with tritium oxide vapor absorbed 98 to $99 \%$ of the HTO vapor ${ }^{(1)}$ during four to five minute exposures. The HTO concentration in venous blood increases rapidly reaching a maximum approximately ten minutcs after the end of the 
exposure. (4) This is followed by an exponential decline (with a half-life near $12 \mathrm{~min}$ ) which is most likely due to the distribution of the tritium oxide in the body. The activity in urine follows a similar pattern, (4) but the increase is somewhat slower, reaching a maximum 25 to 40 min after the exposure. Comparison of the tritium in venous blood with that in urine indicates that there is a $2 \mathrm{hr}$ delay in the establishment of equilibrium between urine and venous blood; therefore, at least a $2 \mathrm{hr}$ delay is expected before the establishment of equilibrium in total body water. Following the establishment of equilibrium in body water, the tritium oxide concentration in body water decreases exponentially with a 9 to 12 day half-life, (4) the half-life for body water turnover.

The uptake of tritium due to inhalation of tritium gas is not as great as that for inhalation of tritium oxide vapor. Current experimental data indicate that humans absorb less than $0.004 \%$ of the tritium gas inhaled; $(4,5)$ oxidation within the body is thought to be responsible for this uptake. Though the exact locus of this oxidation has not been determined, the observation that certain bacteria in the intestinal tract of rodents are responsible for the oxidation of tritium gas (4) suggests that the same may be true in man. For acute exposure, most of the oxidized tritium gas is incorporated in the body water with only a small amount becoming bound in tissue components. (5) The uptake is probably linear with time since the uptake in urine is linear with.time. (4)

\subsection{Percutaneous Absorption from Air}

Large uptake of tritium through the skin has been found for exposures to HTO vapor. (5) The uptake is so efficient that an unclothed 
man submerged in a cloud of HTO may absorb as much tritium through his skin as through his lungs. (4) Pinson and Langham (4) have produced evidence that the absorption rate of water vapor contaminated with HTO $\left(0.018 \mathrm{mg}\right.$ water $\left./ \mathrm{cm}^{2}-\mathrm{min}\right)$ is approximately equal to the loss rate of insensible perspiration of the forearm $\left(0.013 \mathrm{mg}\right.$ water $\left./ \mathrm{cm}^{2}-\mathrm{min}\right)$ under the same conditions. The uptake rate of tritium, therefore, depends on the tritium contamination of the vapor. De Long et al. (6) found that the absorption for one hour exposures of the lower arm to an atmosphere saturated with HTO contaminated water vapor at $30^{\circ} \mathrm{C}$ is $0.0086 \pm 0.0017$ $\mathrm{mg} / \mathrm{cm}^{2}-\mathrm{min}$. They also found that the water absorption in milligrams per square centimeter per minute is directly proportional to the vapor pressure. Correction for this effect increased the discrepancy between this data and that of Pinson et al. (4) It was also observed ${ }^{(6)}$ that the absorption rate of HTO contaminated water vapor is higher for exposures of abdominal skin than for exposures of the forearm. In another instance, the absorption rate per unit area was determined for an exposure of the whole body and was found to be higher than those for exposures of the forearm or abdomen. This result is consistent with pinson's (7) finding that the absorption rate is nearly. equal to the insensible perspiration loss rate.

Following percutaneous absorption of HTO vapor, the HTO is diluted in the body water. Distribution and equilihrium, however, are delayed as evidenced by a $10 \mathrm{~min}$ period between the beginning of the exposure and the appearance of HTO in the urine. After its appearance in the 
urine, the concentration of tritium continues to increase for thirty minutes to several hours. (4) If the skin is warmed, the increase is rapid and peaks around $1 \mathrm{hr}$ after the exposure. If, the skin is chilled, the increase is slower and the peak is reached about $5 \mathrm{hr}$ after the exposure. (4) This is believed to be due to. a change in blood circulation in and/or near the skin. Following equilibrium, the concentration of the HTO in the body water should decline with a half-life. of 9 to 12 days if normal consumption of water is maintained.

The absorption of tritium gas through the skin is less rapid than the absorption of tritium oxide. Eakins, Hutchinson, and Lally (8) exposed a $24 \mathrm{~cm}^{2}$ area of skin to tritium gas at a concentration of 260 $\mu \mathrm{Ci} / \mathrm{cm}^{3}$ but could not detect an increase of tritium in the urine following the exposure.

\subsection{Percutaneous Absorption from a Metal Surface}

Tritium is absorbed by the body when the skin is contacted with a metal surface contaminated with tritium gas or tritium oxide. A study of this mechanism has been performed by Eakins, Hutchinson, and Lally. l'his study is significant to fusion technology since the operation and maintenance of fusion reactors will likely result in skin contact with tritium contaminated surfaces. An experiment in which the inside forearm of one subject was exposed for $10 \mathrm{~min}$ to a brass strip contaminated with adsorbed tritiated water vapor at a concentration of $20 \mu \mathrm{Ci} / \mathrm{cm}^{2}$, indicates that $3.4 \%$ of the applied activity is absorbed through the skin. When similar exposure parameters were employed using the palm, two different subjects absorbed 14.6 and $4.9 \%$ of the applied 
activity. (8) The absorbed tritium remains in the oxide form and is distributed throughout the body water. Its concentration in urine peaks nearly four hours after the exposure, indicating that equilibrium in the body fluids is delayed for at least this length of time. The equilibrium is then followed by an exponential decrease in the concentration with a half-life of 9.5 days. Again, this is the half-life for turnover of body water.

Exposure of the forearm and palm to brass contaminated with tritium gas introduces a smaller tritium activity into the urine. The tritium then appears in urine in two forms: oxide and organic. (8) For 10 min exposures of the inside forearm to brass contaminated with 44 $\mu \mathrm{Ci} / \mathrm{cm}^{2}$ of tritium gas, an average of $0.50 \%$ (range, 0.28 to $0.75 \%$ ) of the applied activity is absorbed and later appears in the urine as tritiated water, while an average of $0.33 \%$ (range, 0.13 to $0.65 \%$ ) of the applied activity is absurbed and emerges in the urine as organic tritium. (8) The tritium oxide and organic tritium concentrations in urine were also followed over time. The tritium oxide concentration in urine initially rises quite rapidly for approximately four hours. During this time about 40 to $50 \%$ of the maximum concentration is reached. The concentration then increases' at a slower rate until the maximum is reached approximately $24 \mathrm{hr}$ after the exposure. The half-life of the subsequent exponential decline in the tritium concentratiun in uxine ranged from 13 to 16 days in the three subjects that were followed. This is slightly longer than the half-life of 9 to 12 days for body water turnover under normal conditions. The organic tritium concentration in urine also reaches a maximum approximately $24 \mathrm{hr}$ after the 
exposure. Following this peak, the organic tritium concentration declines exponentially with two components: Approximately $50 \%$ of the organic tritium is excreted with a half-time of one to two days; the other $50 \%$ is excreted with a half-time of 0.1 to 0.2 days.

\subsection{Conclusions Regarding Radiological Hazards}

Several conclusions can be derived from the above data. First, exposures to tritium oxide vapor are between four and five orders of magnitude more hazardous than exposures to atmospheric tritium gas. This is due totally to the relative absorption of tritium in the two cases. Second, tritium oxide and tritium gas exposures by skin contact with contaminated metal surfaces appear to be approximately equally hazardous. More tritium is absorbed during an exposure to a metal contaminated with tritiated water than with tritium gas, but the faster elimination of the tritium absorbed from the former exposure tends to diminish the difference in the resulting dose. Comparison of the 50 year dose commitment resulting from an exposure of A square centimeters of the palm and forearm to brass contaminated with $Q$ microcuries of tritium oxide per square centimeter, $\left(\left[9.11 \times 10^{-6}\right][\mathrm{Q}][\mathrm{A}] \mathrm{rads}\right)$, with the 50 year dose commitment resulting from the same exposure except to brass contaminated with the same concentration of tritium gas, $\left(\left[7.06 \times 10^{-6}\right][\mathrm{Q}][\mathrm{A}] \mathrm{rads}\right)$, shows that the dose commitments are nearly equal. Highly contaminated surfaces are needed, however, for the percutaneous absorption of tritium from the metal surface to become significant when compared with pulmonary uptake. This can be seen by a comparison of the dose commitments that result from each exposure. For pulmonary absorption of 
tritium during an 8 hour exposure to tritium gas at $5 \times 10^{-5} \mu \mathrm{Ci} / \mathrm{ml}$ the absorbed dose is $3.3 \times 10^{-3}$ rad while the dose commitment from percutaneous absorption during an exposure to a brass surface that has adsorbed tritium from the same environment is $4.0 \times 10^{-9}$ rad, a factor of $10^{6}$ smaller. In the latter calculation, data for the sorption of tritium on brass, obtained by Hutchinson and Eakins, (9) were used. 


\section{SOURCES OF TRITIUM}

The primary contributors to the present tritium inventory are: (1) natural production; (2) nuclear detonations; (3) fission reactors;

(4) fuel reprocessing plants; (5) tritium production and processing facilities; and in the future, (6) thermonuclear reactors. These sources are discussed in detail in another report. (10)

\subsection{Natural Production}

Estimates of the global steady state inventory of naturally produced tritium range from 70 to $140 \mathrm{MCi}$ (2) This tritium is derived from the irradiation of nitrogen-14 and oxygen atoms in the upper atmosphere with cosmic rays, and from the capture of tritium nuclei ejected by stars. Using the tritium distribution given by Jacobs, ${ }^{(2)} 0.070$ to $0.140 \mathrm{MCi}$ of tritium is in the troposphere as HTO, 0.0140 to $0.280 \mathrm{MCi}$ is in the troposphere as HT, 7.0 to $14.0 \mathrm{MCi}$ appear in the stratosphere as HTO and 0.00280 to $0.00980 \mathrm{MCi}$ is in the stratosphere as $\mathrm{HT}$; most of the remainder is in the hydrosphere.

\subsection{Nuclear Detonations}

Fission and fusion weapons have contributed largely to the world tritium inventory. The contribution from atmospheric detonation of fusion weapons (6.7-48 megacuries/megaton equivalent explosion, $\mathrm{MCi} / \mathrm{Mt}$ ) is larger than that from the atmospheric detonation of fission weapons (2 MCi/Mt). (12) The tritium inventories in 1963 due to fusion explosions and due to fission explosions have been reported as $3100 \mathrm{MCi}$ and $300 \mathrm{MCi}$, respectively. (10) in other estimates, the inventory due to weapons 
tests ranges from $1700 \mathrm{MCi}{ }^{(13)}$ to $8000 \mathrm{MCi}{ }^{(11)}$ of tritium. Underground explosions release less tritium to the atmosphere with the amount of release depending on the containment of the explosion. Estimates (11) of the upper limit of tritium release in 17 vented radioactivity tests have determined (based on the assumption that HT and HTO releases are the same as those for rare gases) that $1.2 \times 10^{-7}$ to $1.2 \times 10^{-2} \mathrm{MCi}$ of tritium were released to the atmosphere per year. During this period the detonation rate was $60 \mathrm{kT} /$ year (kiloton/year). (11)

Only a small fraction of the tritium released to the atmosphere from underground or atmospheric weapons tests is elemental tritium. $(2,11)$ In atmospheric detonations a majority of the tritium is oxidized as a result of the high temperatures of the detonation. Nevertheless, the atmospheric concentrations of elemental tritium and tritium incorporated in methane gas are significantly increased following the detonation. For underground detonations, a reasonable upper limit for tritium in the elemental form is $1 \%$ of the release. (11)

\subsection{Fission Reactors}

Water cooled fission reactors produce tritium by ternary fission of the fuel, by activation of structural and component material, and by activation of the coolant. Most of the tritium released from these reactors is released as tritiated water either in the liquid or vapor phase, but some tritium gas is also released along with the gaseous effluent. It is typical for the gaseous effluent to contain $<0.25$ to $10 \%(14)$ of the total tritium released from a PWR (pressurized water reactor) while for BWRs (boiling water reactors) the tritium released 
with the gaseous effluents has varied from 1 to $30 \%$ of the total tritium. $(14,15)$ The Chalk River Reactor $\left(42 \mathrm{MW}_{(\mathrm{t})}\right)^{(16)}$ typical of HWRs (heavy water reactors) releases $3 \mathrm{Ci}$ of tritium to the stack per year. (2)

The treatment of the gaseous effluent determines the partitioning of the gaseous tritium stream into the elemental and oxidized forms. Treatments are so different that a wide variation in this fraction is found. In BWRs, one study found that most of the tritium released with the gaseous effluents had an elemental form, while another ${ }^{(17)}$ showed that most was released as a vapor. Similar data on PWRs were not found. In HWRs any tritium that is available for release must first enter the heavy water coolant whose chemistry indicates that elemental tritium will not be released. (2) Therefore, most of its gaseous effluent is water vapor.

Several advanced reactor designs are being developed and may become available in the future. These are the Liquid Metal Fast Breeder Reactor (LMFBR), the High Temperature Gas Cooled Reactor (HTGR), and the Molten Salt Breeder Reactor (MSBR). Based on design concepts and experience with small scale experimental breeder reactors and fast flux test facilities, it can be estimated that the LMFBR will release approximately $57 \mathrm{Ci}$ of tritium per $1000 \mathrm{MW}(\mathrm{e})$-year to the air primarily as tritium gas and $3 \mathrm{Ci}$ of tritium per $1000 \mathrm{MW}_{(\mathrm{e})}$-year as liquid HTO. (10) It is expected $(10)$ that the total release from a HTGR will be around $200 \mathrm{Ci}$ per ycar. Experience with the low power Peach Bottom HTGR indicates that $62 \%$ of the tritium released from the reactor will be released in the gaseous effluent; ${ }^{(15)}$ the HTO and HT fractions are not available. Releases from MSBRs cannot yet be determined since they are in the development stage. 


\subsection{Fuel Reprocessing}

Tritium is also released during the reprocessing of nuclear fuel. This tritium is produced during reactor operation and retained in the fuel. At the Allied-Gulf Nuclear Services Plant (capacity of 1500 MTU of fuel per year), (18) $5 \%$ of the tritium released from the stack is expected to be HT gas, (18) with the balance being released as HTO vapor; this would correspond to $3.35 \times 10^{4} \mathrm{Ci} /$ year of HT gas and $6.37 \times 10^{5}$ Ci/year of HTO vapor. (18) At the Nuclear Fuel Services Facility (operated from April 1966 to carly 1972), 1.3\% of the tritium in the fuel was released to the environment via the dissolver off gas. (19) Approximately $75 \%$ of this had the form of water vapor. $\left(20^{\circ}\right)$ If the facility had been expanded to 750 MTU per year as proposed, the release would be approximately $1.4 \times 10^{4} \mathrm{Ci} /$ year as HTO vapor and $4.6 \times 10^{3} \mathrm{Ci} /$ year as HT gas. (19) The actual release would vary with the burnup of the fuel.

\subsection{Tritium Production Facilities}

The Savannah River Plant near Aiken, South Carolina, produccs tritium in large quantities. It is formed by irradiating aluminum-1ithium Eargets in heavy water moderated reactors (as well as by mechanisms that normally occur in power HWRs). Tritium is released from the reactor, from the target recovery facility, and from the fuel reprocessing facility. The releases from the HWR are the same as those found in power HWRs so that all of the gaseous release is DTO vapor. From 1970 to 1974 the average gaseous release from the reactors was $231 \mathrm{Ci} /$ year. (21) Most of the atmospheric release from the production process is as elemental tritium from the target processing facility since HTO vapor 
is condensed and released as liquid to seepage basins. The average gaseous release from the processing facilities from 1970 to 1974 was $408 \mathrm{Ci} /$ year.

Large quantities of elemental tritium gas have been accidentally released from the Savannah. River Plant on two recent occasions. The first occurred on May 2, 1974, when 479,000 Ci were released, ${ }^{(22)}$ the second occurred on December 31, 1975, when 182,000 $\mathrm{Ci}$ were released. These releases were due to valve failures in the processing system.

\subsection{Thermonuclear Reactors}

The first generation of thermonuclear reactors will use tritium and deuterium as a fuel. For this reason a large tritium inventory will be required. The total tritium inventory is expected to be between 1 and $15 \mathrm{~kg}$ (9.7-14.5 MCi) for a.5000 MW $(t)$ reactor. ${ }^{(10)}$ Much of this will be stored as fuel reserve. Significant inventories will also appear in the blanket, intermediate coolant, and the tritium recovery, processing, and injection systems. Normal releases of tritium are expected to be reasonably low, $\leq 10 \mathrm{Ci} /$ day to surface waters for a $1000 \mathrm{MW}(t)$ reactor $(24,25,26,27)$ and $2 \mathrm{Ci} /$ day to the atmosphere. $(24,25,28)$ Draley et al. predicted that leakages to the steam system will be $31 \mathrm{Ci} / \mathrm{day}$.

\subsection{Conclusions Concerning the Sources of Tritium}

In the past, evaluations of the hazard from an exposure to tritium have assumed that the tritium is completely in the oxide form. Based on the above discussion of the source of tritium, such an assumption was acceptable since most of the releases of tritium to the atmosphere have 
primarily had the form of tritium oxide or have been much lower than the background inventory. Two obvious exceptions were the accidental releases of tritium gas from the tritium production facility at Savannah River. The increased tritium inventories that will be required to fuel the first generation of fusion reactors are expected to increase the likelihood of an accidental release of tritium gas or exposures of maintenance personnel to tritium as a gas. Accurate assessments of the radiological hazard from such exposures will require a knowledge of the conversion rate of tritium gas to tritium oxide. 


\section{PREVIOUS STUDIES}

The conversion of tritium to tritium oxide under a variety of environmental conditions has been studied in the past. The foundation for these studies was laid by S. C. Lind ${ }^{(29)}$ in his study of the combination of hydrogen and oxygen in an alpha radiation field. It was found in this study that 3.92 water molecules are formed per ion pair produced. A. L. Marshall ${ }^{(30)}$ also studied the combination of hydrogen and oxygen using cathode rays to initiate the reaction. He produced convincing evidence that the mechanisms for the combination of oxygen and hydrogen induced by cathode rays are similar to those for their combination in an alpha radiation field.

\subsection{HT $\rightarrow$ HTO Conversion in Dry Gas Mixtures}

Dorfman and Hemmer (31) were the first to study the oxidation of tritium in its own radiation field. A mixture of protium, tritium, and oxygen was used although the primary interest was the reaction

$$
2 \mathrm{~T}_{2}+\mathrm{O}_{2} \rightarrow 2 \mathrm{~T}_{2} \mathrm{O}
$$

If it is assumed that water ( $\mathrm{HTO}, \mathrm{T}_{2} \mathrm{O}$, or $\mathrm{H}_{2} \mathrm{O}$ ) is the only reaction product and that water vapor, oxygen gas, and hydrogen gas (protium and tritium) are ideal gases, the mass balance can be represented by:

$$
\mathrm{P}_{\mathrm{W}} / 2 \Delta \mathrm{P}=1
$$

where $P_{W}$ is the pressure of water vapor and $\Delta P$ is the change in the total pressure of the system. The change in the total pressure was measured at the end of the experiment. By measuring the pressure of the 
water vapor the mass balance formula coüld be used to evaluate the assumption that water is the only product formed. Values of $\mathrm{P}_{\mathrm{w}} / 2 \Delta \mathrm{P}$ as high as 0.97 and 0.98 were obtained which indicate that any hydrogen peroxide formed must have a transitory existence or must not be formed at all. (31) This result is supported by the works of Lind (29) and Marshal1.(30)

Reduction of Dorfman and Hemmer's ${ }^{(31)}$ data shows that, if correction is made for a secondary effect, the initial rate is directly proportional to the tritium concentration. The secondary effect is a dependence of the reaction rate on the mole fraction of protium in the hydrogen reactant. This effect can be seen in Fig. 4.1 .1 which is a plot of the initial rate divided by the initial tritium concentration (measured as tritium pressure) against the mole fraction of protium in the hydrogen reactant. To approximate this effect, a linear relationship between the ratio of the initial rate to the initial tritium concentration and the initial mole fraction of protium in the hydrogen reactant is assumed. Therefore, the initial reaction rate can be represented by

$$
\mathrm{R}_{\mathrm{o}}=\mathrm{k}\left[\mathrm{T}_{2}\right]_{0}\left(1+\mathrm{bm}_{\mathrm{H}}\right)
$$

where $k_{0}$ is the initial reaction rate, $\left\lfloor T_{2}\right\rfloor_{0}$ is the initial tritium concentration, $\mathrm{k}$ is the rate constant in minutes ${ }^{-1}, \mathrm{~b}$ is the isotope correction factor, and $\mathrm{m}_{\mathrm{H}}$ is the mole fraction of protium in the hydrogen reactant. (31) The value of $b$ is 0.3 , and the average value of $k$ is $1.19 \times 10^{-4} \mathrm{~min}^{-1} .(31)$ 'l'his equation is shown in Fig. 4.1 .2 where Dorfman and Hemmer's ${ }^{(31)}$ data have been used to plot $\mathrm{R}_{\mathrm{o}} /\left(1+0.3 \mathrm{~m}_{\mathrm{H}}\right)$ against the initial tritium pressure. The data points fit a straight line through the origin as expected. 


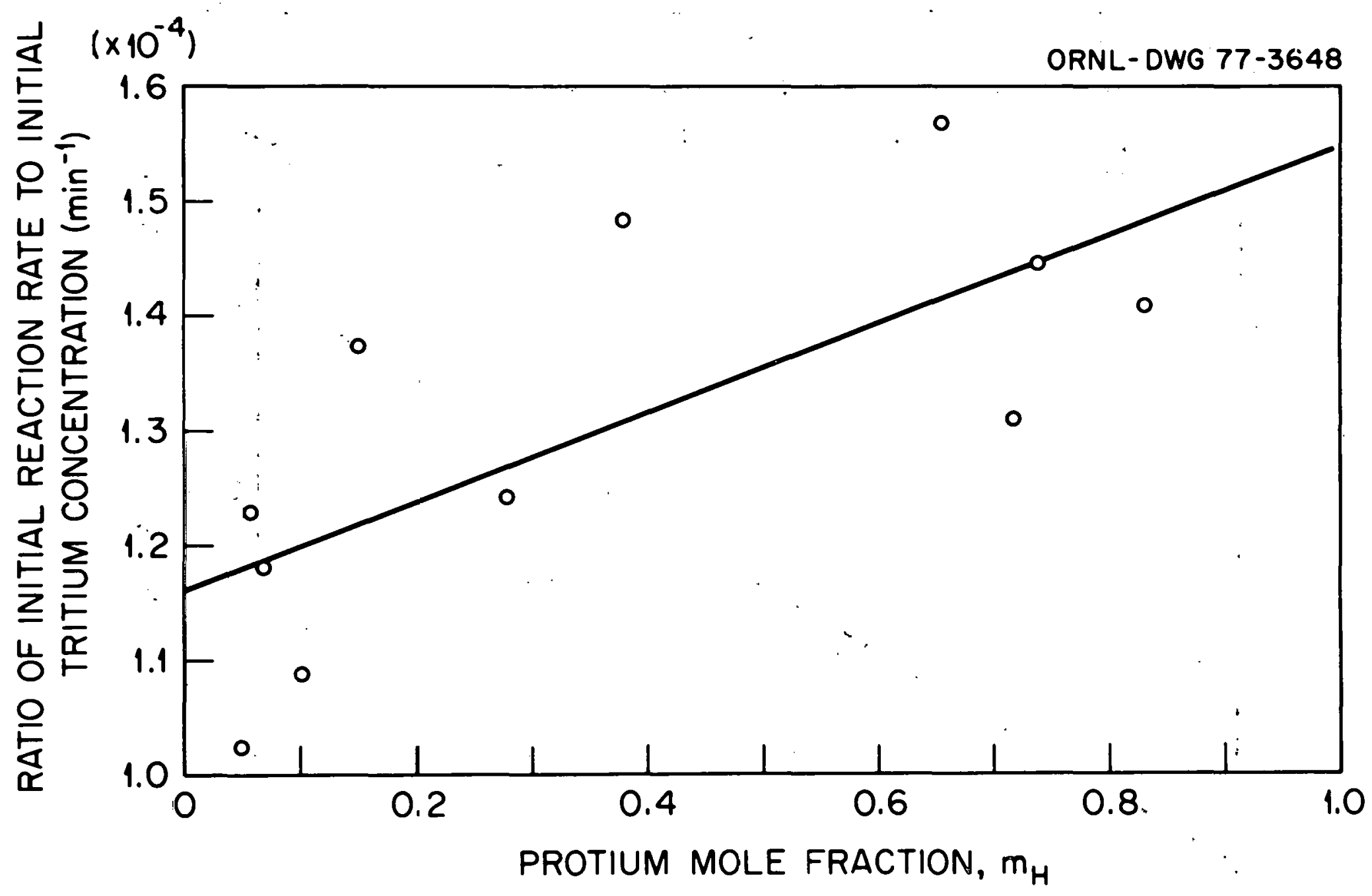

Fig. 4.1.1. Dependence of the reaction rate on the protium mole fraction (from Dorfman and Hemmer, ref. 31). 


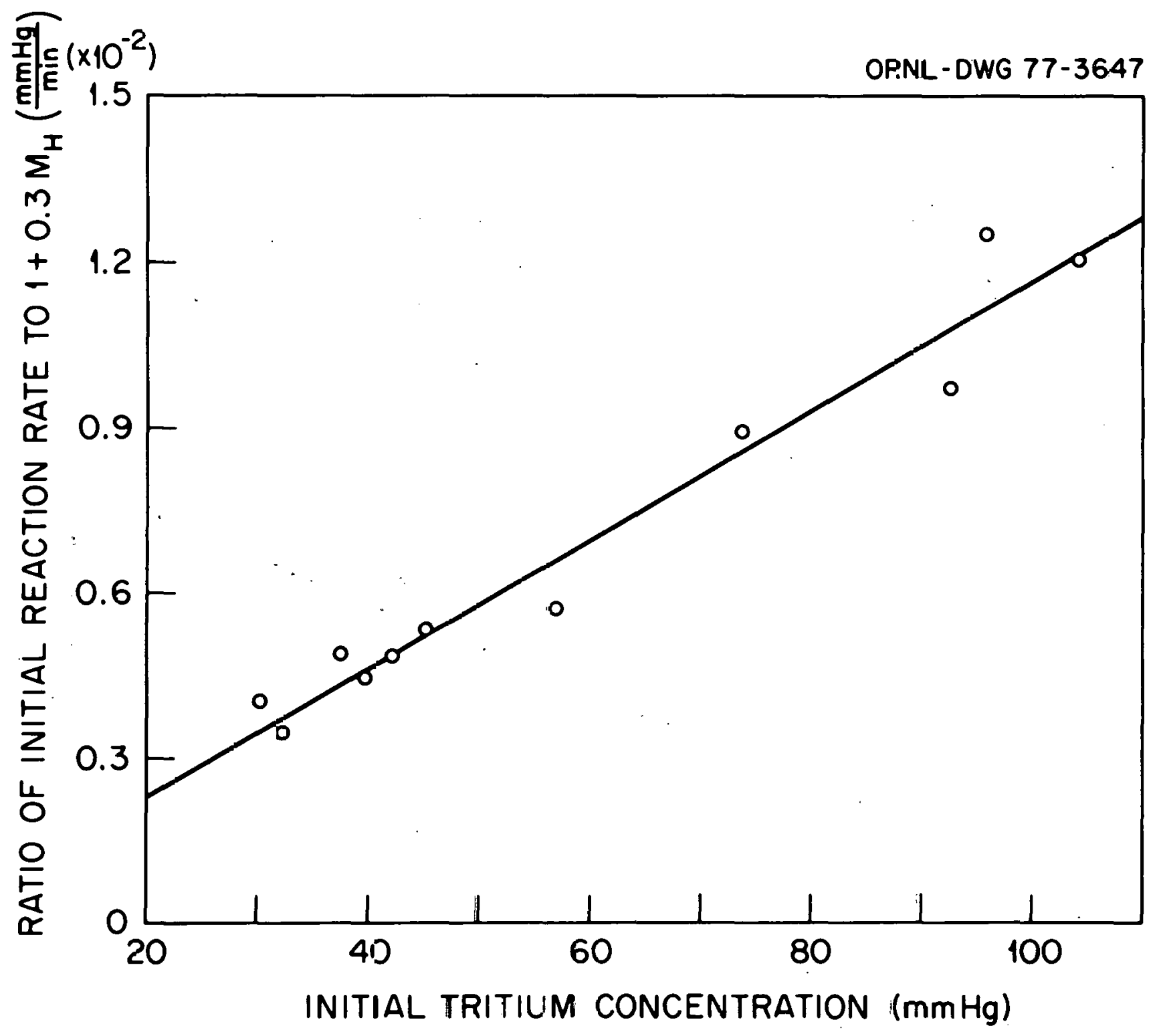

Fig. 4.1.z. Initial reaction rate corrected for the proticm mole fraction of the hydroger. ges as a function of the initial tritium concentration (from Dorfman and Henmer, ref. 31). 
High initial tritium concentrations

The reaction yield in terms of water molecules produced per ion pair formed by tritium decay should be independent of the initial concentration since: (1) the initial reaction rate is proportional to the initial tritium concentration, and (2) the initial tritium concentration is proportional to the number of ion pairs produced. It can be determined that the initial yield of water molecules per ion pair was 3.2 molecules of water per ion pair produced by assuming an energy requirement of $33 \mathrm{eV}$ per ion pair. If the isotopic effect is accounted for, the yield becomes 4.2 molecules of water per ion pair produced which compares well with the value of 3.92 from Lind. (29) So, Dorfman and Hemmer ${ }^{(31)}$ found that the self-oxidation of tritium follows a first order reaction of the form

$$
R_{0}=k_{1}\left[T_{2}\right],
$$

for initial tritium concentrations ranging from $94.5 \mathrm{mCi} / \mathrm{ml}$ to 326.5 $\mathrm{mCi} / \mathrm{ml}$.

\section{Lower initial tritium concentrations}

Casaletto et al. (32) later extended the data of Dorfman and Hemmer to lower initial tritium concentrations ranging from $1.6 \times 10^{-2} \mathrm{mCi} / \mathrm{ml}$ to $3.3 \mathrm{mCi} / \mathrm{ml}$. The oxidation reaction took place in an oxygen environment at a total pressure of $700 \mathrm{~mm}$ of mercury. The results of Dorfman and Hemmer ${ }^{(31)}$ indicated that the initial reaction rate would have a first order dependence on the initial tritium concentration:

$$
R_{0}=-\frac{d\left[T_{2}\right]_{0}}{d t}=k_{1}\left[T_{2}\right]_{0}
$$


where $R_{0}$ is the initial reaction rate, $\left[\mathrm{T}_{2}\right]$ is the tritium concentration, $t$ is the time, $k_{1}$ is the first order reaction rate constant, and the subscript "o" indicates initial conditions. However, Casaletto et al.

found that this relation does not hold for the initial tritium concentration range in which they were working. They plotted the first order reaction rate constant $k_{1}$ against the initial tritium concentration and obtained the results shown in Fig. 4.1.3. The straight line obtained in the $\log k_{1}$ vs. $\log \left[\mathrm{T}_{2}\right]_{0}$ plot making a 45 degree angle with the abscissa indicates that $\mathrm{k}_{1}$ is directly proportional to the initial tritium concentration, $\left[\mathrm{T}_{2}\right]_{0}$ :

$$
\mathrm{k}_{1}=\mathrm{k}_{2}\left[\mathrm{~T}_{2}\right]_{0}
$$

Substituting this into Eq. 4.1 .3 gives

$$
\mathrm{k}_{0}=-\frac{\mathrm{d}\left[\mathrm{T}_{2}\right]_{0}}{\mathrm{dt}}=\mathrm{k}_{2}\left[\mathrm{I}_{2}\right]_{0}^{2}
$$

Therefore, the initial reaction rate has a second order dependence on the initial tritium concentration. For the expression of the reaction rate as a function of time, Casaletto et al. (32) proposed the equation

$$
R_{t}=-\frac{d\left[T_{2}\right]_{t}}{d t}=k_{2}\left[T_{2}\right]_{o}\left[T_{2}\right]_{t}
$$

Here, $\left[\mathrm{T}_{2}\right]_{t}$ represents the tritium concentration at time $t$, and $\left[\mathrm{T}_{2}\right]_{0}$ represents the initial tritium concentration as before. This equation was deduced by reasoning that the formation of tritium water does not remove the tritium beta radiation from the vessel; so, one of the tritium terms should remain as $\left[\mathrm{T}_{2}\right]_{0}$ to account for the radiation intensity. 


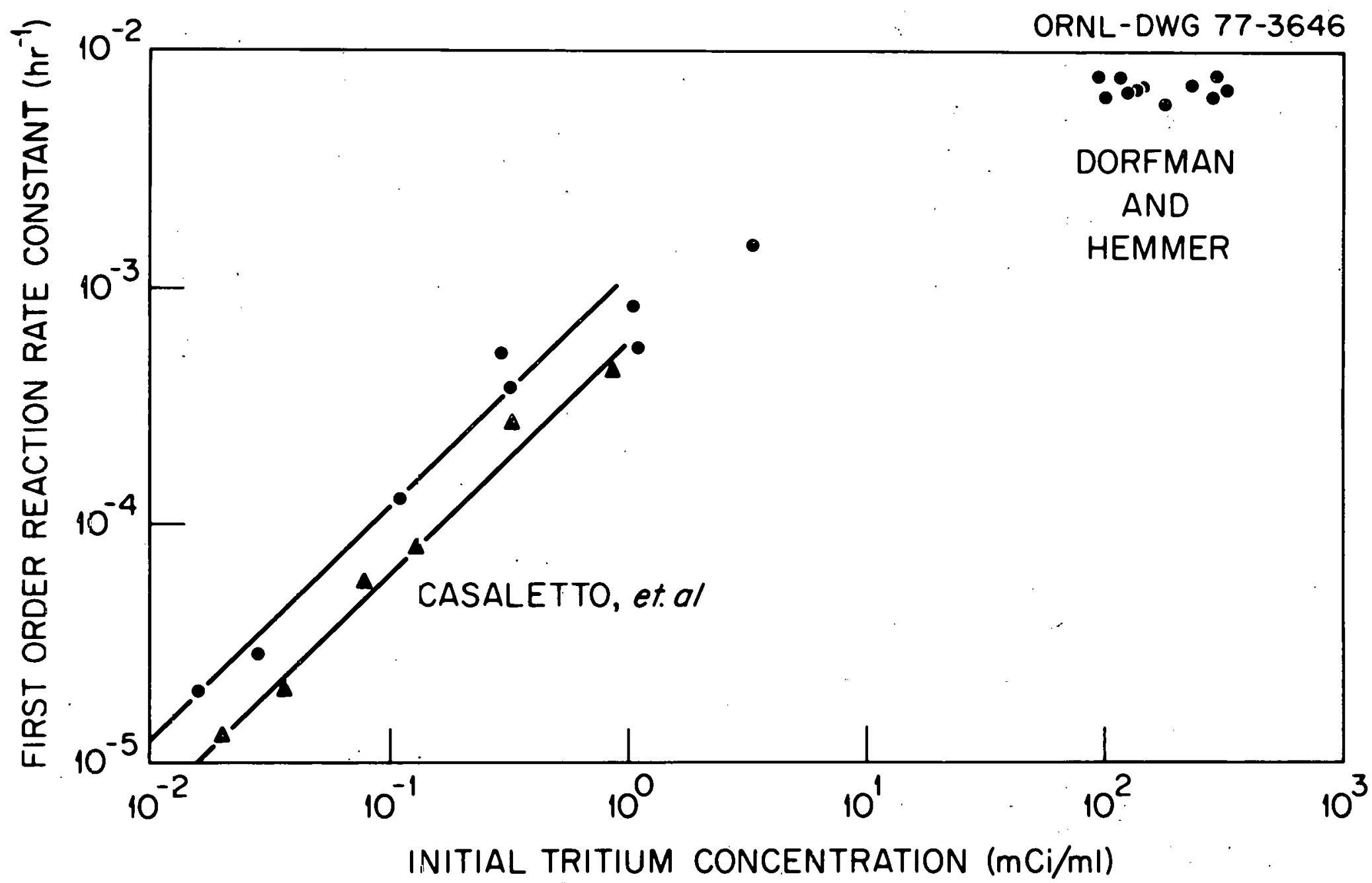

Fig. 4.1.3. First order reaction rate constant as a function of initial tritium concentration (from Casaletto et al., ref. 32). $\mathbf{\Delta - d r y ~ a i r ; ~ - ~ o x y g e n , ~ t r i t i u m ~ g a s ~}$ mixture. 
This equation has not been verified. The experiment ${ }^{(32)}$ gave a second order rate constant of $1.2 \times 10^{-3} \mathrm{ml} / \mathrm{mCi}-\mathrm{hr}$ for an oxygen environment and a second order rate constant of $6.2 \times 10^{-4} \mathrm{ml} / \mathrm{mCi}-\mathrm{hr}$ for a dry air environment.

Casaletto et al. ${ }^{(32)}$ also attempted to determine if a change in the oxygen concentration is responsible for the reaction rate in dry air being smaller than the reaction rate in oxygen. To do this they varied the oxygen concentration over three orders of magnitude. The total pressure in each reaction was $700 \mathrm{~mm}$ of mercury which was obtained by adding nitrogen or helium gas to the reaction flasks. This was done to insure that the beta energy absorbed by the gases in each experiment was nearly constant. This series of experiments showed the reaction rate to be independent of the oxygen concentration even for very low oxygen concentrations. Very low oxygen concentrations were obtained by allowing the tritium to oxidize in reagent grade helium or commercial helium purified by passage through a charcoal column at liquid nitrogen temperatures. Although the oxygen concentrations were not given in these cases, they were certainly very low.

A third investigation performed by Belovodskii et al. (33) extended over the total initial concentration range covered by Casaletto et al. (32) and Dorfman and Hemmer. (31) The conversion was allowed to occur in a tritium, argon, and oxygen mixture, and the rate was found to be propurtional to the $5 / 3$ power of the initial tritium concentration over the whole range. Also, the rates were slightly slower than the rates determined by Casaletto et al. 


\subsection{HT $\rightarrow$ HTO Conversion in Moist Gas Mixtures}

In addition to the above experiments, studies have been undertaken to investigate the conversion of tritium gas to tritium oxide in the presence of various other substances. Probably the most important of these substances is water vapor. Water vapor is unique since the tritium atom can exchange with the other isotopes of hydrogen in the water molecule to form a tritiated water molecule. The isotopic exchange of water has been studied by Yang and Gevantman. (34) They determined the tritiated water product for various combinations of tritium concentration, water vapor density, and moderating gas. The inclusion of the moderating gas insures complete beta energy absorption in the gases. The rate of tritiated water formation at an initial tritium concentration of $52 \pm$ $1 \mathrm{mCi} /$ liter is reported to be unaffected by nearly a fourfold change in the water vapor density but is affected by the tritium concentration. (34) The dependence on the tritium concentration is shown in Fig. 4.2.1 which is a log-log plot of the exchange rate $\mathrm{R}_{\mathrm{e}}$ versus the initial tritium concentration $\left[\mathrm{T}_{2}\right]_{0}$. When helium is used as the moderating gas the slope of the line drawn through the points indicates a second order dependence of $R_{e}$ on $\left[T_{2}\right]_{0}$. The resulting equation is:

$$
\frac{\mathrm{d}(\mathrm{HTO})}{\mathrm{d} t}=\mathrm{R}_{\mathrm{e}}=3.6 \times 10^{-5}\left(\mathrm{~T}_{2}\right)_{\mathrm{O}}^{2} \frac{1 \text { iter }}{\mathrm{mC} i-\mathrm{day}},
$$

where $\mathrm{d}(\mathrm{HTO}) / \mathrm{dt}$ has the units of $\mathrm{mCi} / 1 \mathrm{iter}-\mathrm{day}$ and $\mathrm{T}_{2}$ has the units of $\mathrm{mCi} /$ liter. Therefore, the reaction rate constant is

$$
\mathrm{k}_{2} \mathrm{e}=3.6 \times 10^{-5} \frac{\text { liter }}{\mathrm{mCi} \text { day }}=1: 5 \times 10^{-3} \frac{\mathrm{ml}}{\mathrm{mCi}-\mathrm{hr}} .
$$




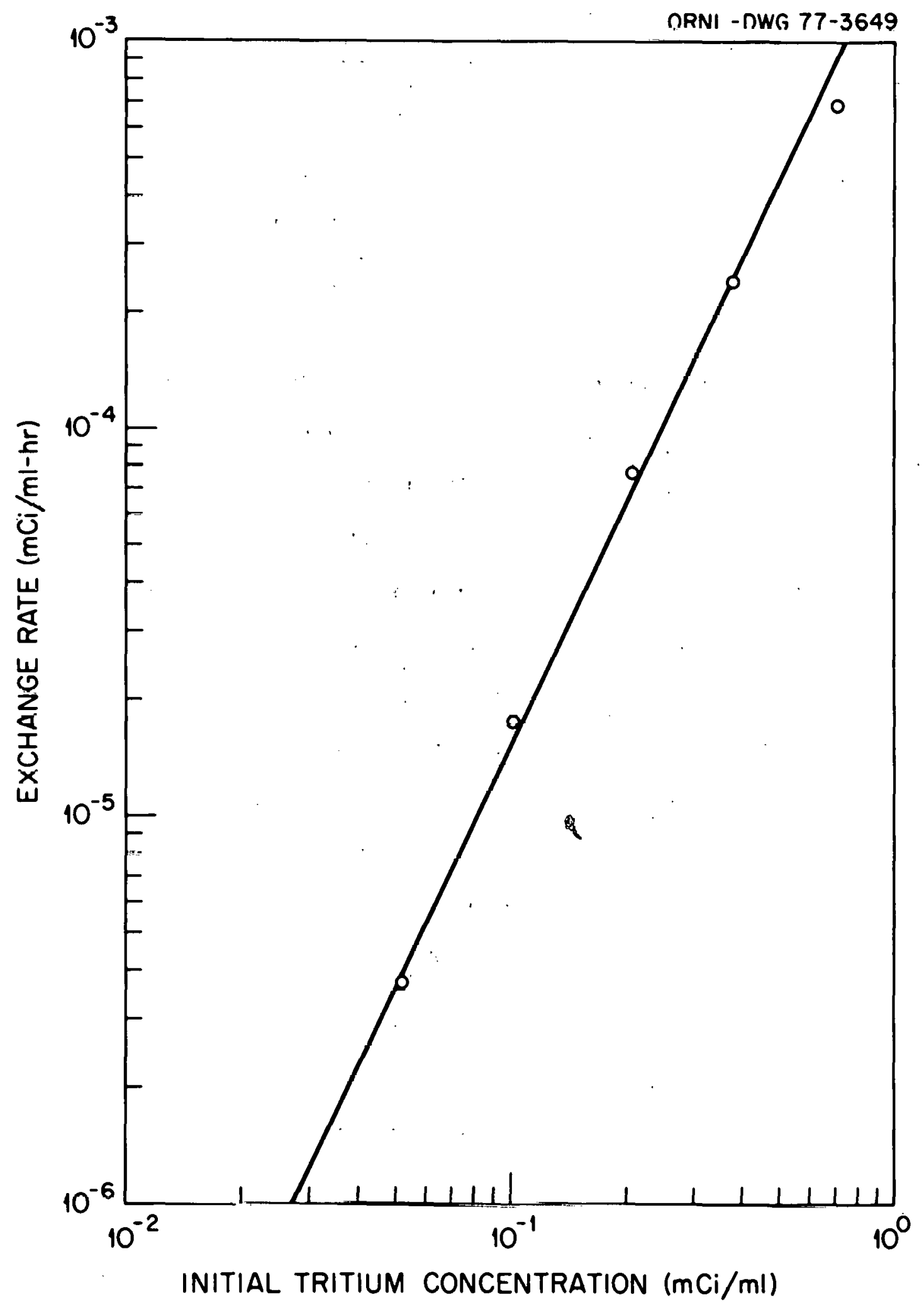

Fig. 4.2.1. The rate of formation of HTO by the exchange of a tritium atom with a protium atom in a water molecule as a function of initial tritium concentration (from Yang and Gevantman, ref. 34). 
It was also determined that the reaction rate is inversely dependent on the first ionization potential of the moderating gas atom. The dependence, however, is small.

Later, Casaletto et al. ${ }^{(32)}$ reevaluated the effect of water vapor on the conversion of tritium to tritiated water. Their results using a mixture of tritium and water vapor duplicated those of Yang and Gevantman. (34) Runs were also made for mixtures of tritium, oxygen, and water vapor. The rate of reaction was approximately twice that for dry oxygen, but the results were not sufficiently precise to allow an accurate determination of the rate. (32) Smith, however (as reported by Casaletto et al. ${ }^{(32)}$ ), found a second order rate constant of $4.3 \times 10^{-3}$ $\mathrm{ml} / \mathrm{mCi}-\mathrm{hr}$ for the tritium, oxygen, water vapor mixture; this is larger than the sum of the second order rate constants for the oxidation reaction and the exchange reaction. Belovodskii et al. (33) found that the conversion rate in a moist-tritium-dry air mixture is no different than that in a tritium-argon-oxygen mixture. They concluded that water vapor does not affect the conversion rate significantly.

\subsection{Surface and Pressure Effects}

Eakins and Hutchinson ${ }^{(35)}$ have studied the conversion of HT to HTO in the presence of brass, steel, aluminum, and platinum. In dry air there was a marked increase in the reaction rate constant for all of the metals except brass. Platinum gave the largest increase. In moist air, all four metals increased the second order reaction rate constant. This study indicates that a catalyzing effect does exist. (35) 
Two additional studies investigating the effects of surface area and total pressure on the rate of tritium oxidation have been performed by Casaletto et al. (32) In order to determine how a change in the surface area of the reaction flask influences the oxidation rate, the oxidation reaction was carried out using a tritium and oxygen mixture contained in indented bulbs and in unindented bulbs. The surface-tovolume ratio for the indented bulbs was three times that for the unindented bulbs. There was no significant difference noted in the two cases; ${ }^{(32)}$ so, the surface of the bulb does not affect the reaction significantly. In a study of the effect of total pressure on the rate, the oxidation reaction was performed using a tritium and oxygen gas mixture. Different total pressures were obtained by varying the oxygen concentration. Above $100 \mathrm{~mm}$ of mercury, the rate was constant, but at $20 \mathrm{~mm}$ of mercury the rate was $10 \%$ of the maximum value and at $5 \mathrm{~mm}$ of mercury it was $0.5 \%$ of the maximum value. ${ }^{(32)}$ The reduction in rate can not be totally due to a loss of beta energy since the drop-off in the reaction rate as the pressure decreases is much more rapld than the drup in the absorbed beta energy. (32)

\subsection{Conclusions from Previous Studies}

From these investigations, several conclusions may be drawn. First, the initial rate of tritium oxidation is proportional to the square of the initial tritium concentration when $\left[\mathrm{T}_{2}\right]_{0}$ is between $1.6 \times 10^{-2} \mathrm{mCi} / \mathrm{ml}$ and $3.3 \mathrm{mCi} / \mathrm{ml}$ but is proportional to $\left[\mathrm{T}_{2}\right]_{\mathrm{o}}$ when $\left[\mathrm{T}_{2}\right]_{\mathrm{o}}$ ranges from 94.5 to $326.5 \mathrm{mCi} / \mathrm{ml}$. The dependence at the higher tritium concentrations, however, is suspect since extrapolation of data was made and since a 
nonspecific analysis of the reaction was used. Second, tritium can be converted to tritium oxide by a separate process if water vapor is present. This is called isotopic exchange, in which a tritium atom replaces a protium atom in the water molecule. The rate of isotopic exchange is proportional to $\left[\mathrm{T}_{2}\right]_{0}^{2}$ for initial tritium concentrations on the order of those used by Casaletto et al. ${ }^{(32)}\left(1.6 \times 10^{-2} \mathrm{mCi} / \mathrm{ml}\right.$ to $3.3 \mathrm{mCi} / \mathrm{ml})$. Other observations are that: the oxidation reaction rate is independent of the oxygen concentration down to very low oxygen concentrations; the isotopic exchange reaction rate is independent of the water vapor concentration over a fourfold range (5.0 to $17.5 \mathrm{mg} / 1 \mathrm{iter})$; the oxidation rate is slower in dry air than in pure oxygen, and the oxidation rate is independent of the surface area of the reaction flasks but is slightly catalyzed by metals. 


\section{EXPERIMENTAL ME'I'HODS}

Initial experiments were performed by allowing tritium gas to react forming tritiated water in the presence of dry air, dry air with soil and moist air. The experimental apparatus, contained in a hood, consists of a pumping and backfilling manifold and a tritium recovery system. The first consists of an oil diffusion pumping system, a uranium trap (for the tritium), pressure sensors and a manifold for expanding tritium and other gases into the 1 liter reaction flasks. At discrete time intervals, approximately $9 \mathrm{ml}$ of gas is removed from the reaction flasks and passed through the tritium recovery system which consists of a set of water bubblers to collect the HTO, a copper oxide furnace to convert the unreacted HT to HTO and a second set of bubblers. Liquid scintillation counting of the bubbler water is used to provide a measurement of the reacted and unreacted tritium.

\subsection{Apparatus}

\section{Tritium sunply system}

Tritium was supplied for the experiment in an activated uranium trap. Such a trap offers the following advantages:

1. Safe handling and transfer of tritium gas;

2. Safe, simple introduction of tritium into the reaction flasks;

3. Ability to resorb tritium, thereby reducing releases to the environment.

A disadvantage of the trap is the pyrophoric nature of activated uranium. If a sufficient volume of air is admitted to the trap, the uranium could ignite and could conceivably release enough heat to melt the stainless 
steel container and release tritium gas. This was not a problem since the trap was kept at a pressure of less than $10^{-3}$ torr.

In order to prepare the trap, approximately $0.5 \mathrm{~g}$ of depleted uranium turnings (whose capacity for tritium is around $83 \mathrm{Ci}$ ) was placed in a hollow stainless steel tube (5/16 in. O.D.) sealed at one end. The. tube was then packed with steel wool to prevent the escape of uranium during the activation process. The open end of the tube was connected to an all metal valve. A furnace was also designed and fabricated for the trap. The heating element of the furnace was a boron nitride spool designed to fit snugly around the stainless steel trap. This spool was wound with nichrome wire at 10 turns per inch. An electrical insulating sleeve of lavite was machined to slip over the heating element. The leads of the heating element were connected to a variable transformer so that the temperature of the furnace could be regulated.

After these preparations were completed, the trap was ready for activation. Activation was performed according to the procedure of Ahmann, Flint, and Salmon. (36) The procedure was:

1. Evacuate the trap to $1.0 \times 10^{-5}$ to $5 \times 10^{-5}$ torr;

2. Isolate the system from the pumps making the system static;

3. Backfill the system with hydrogen gas to approximately 1 atmosphere pressure;

4. Heat the trap to $300^{\circ} \mathrm{C}$ and allow the uranium to react with the hydrogen for 15 to $20 \mathrm{~min}$ forming uranium hydride $\left(\mathrm{UH}_{3}\right)$, a gray black finely divided compound;

5. Reopen the system to the pumps and increase the trap temperature to $400^{\circ} \mathrm{C}$;

6. Evacuate the trap to $1.0 \times 10^{-5}$ to $5.0 \times 10^{-5}$ torr. 
This procedure was repeated three times to ensure complete activation of the uranium trap. The trap was then sent to the Oak Ridge National Laboratory (ORNL) Isotope Sales Division for charging with approximately $4 \mathrm{Ci}$ of $\mathrm{T}_{2}$.

\section{Vacuum system}

A vacuum system was required so that the reaction flasks could be evacuated to control the reaction environment and the uranium trap supplying the tritium could be protected from exposure to air at atmospheric pressure. The vacuum system was generally evacuated to a pressure of $1.0 \times 10^{-5}$ torr by means of a two-inch oil diffusion pump, the intake of which was attached to the vacuum system via a two-inch water baffle. This baffle reduced the backstreaming of pump oil into the system.

The system itself consisted of a metal manifold, a liquid nitrogen trap, and a glass manifold (see Figure 5.1.1). The metal manifold, to which the diffusion pump was attached, housed three pressure yauges, an ionization gauge, and two thermocouple gauges (0-1000 microns and $10^{-4}$ to $10^{-2}$ torr). The metal manifold also provided an access to the system for the uranium trap. The remaining end of the metal manifold was connected to a liquid nitrogen trap via a short tygon tube. l'his trap removed any tritium oxide present in the tritium source before it could reach the reaction flasks. The trap was a 1 liter dry gas wash bottle which was half submerged in a liquid nitrogen bath.

The glass manifold functioned as an access to the vacuum system for three reaction flasks. It was desired that the manifold could be isolated from the reaction flasks; therefore, each port contained a $4 \mathrm{~mm}$ bore precision ground stopcock. 
ORNL DWG $77-7897$

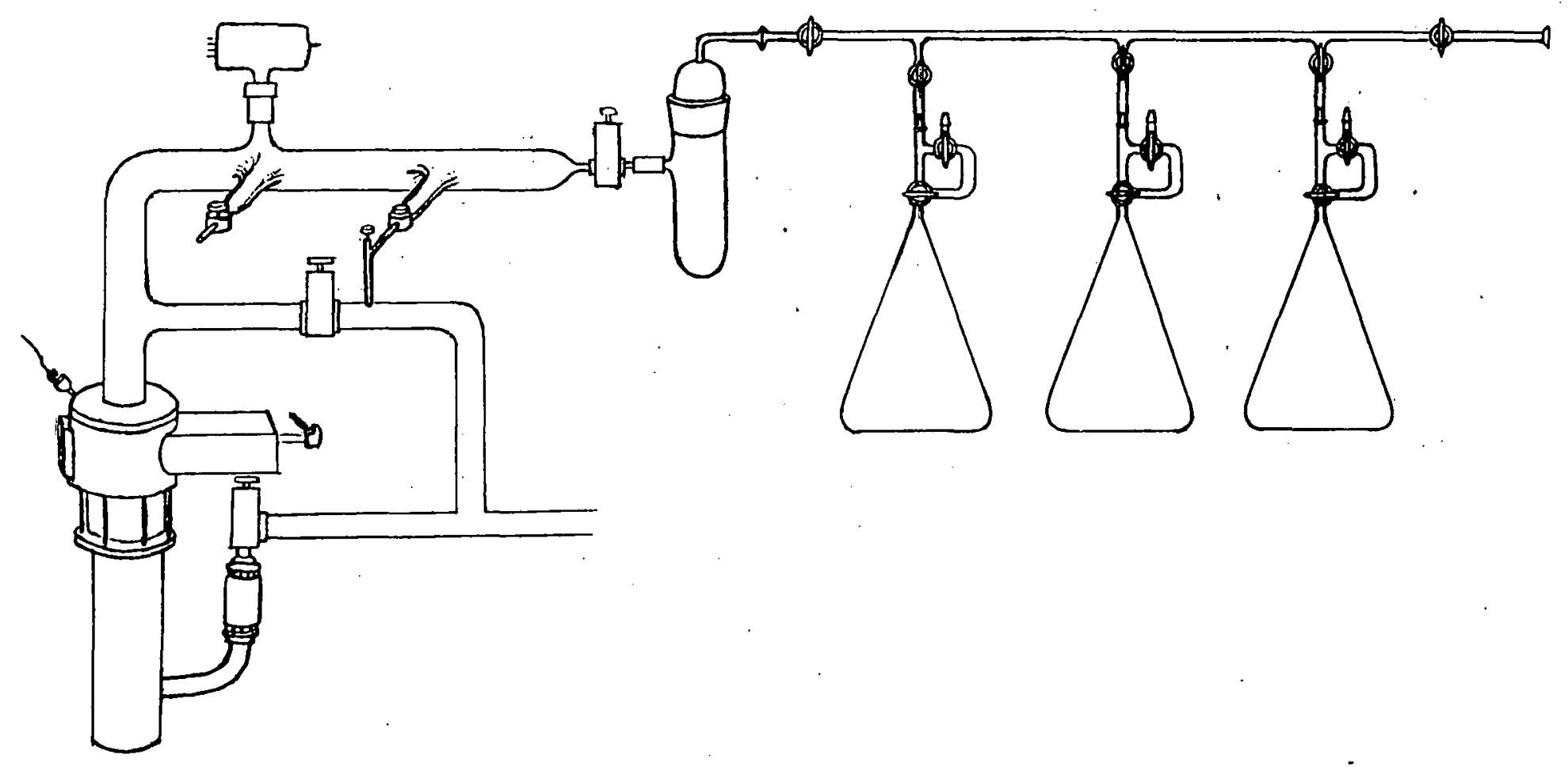

Fig. 5.1.1. Vacuum system for evacuating the reaction flasks and backfilling the flask with tritium gas. 
Reaction flasks

Tritium was oxidized in three modified 1 liter Erlenmeyer flasks. Multiple sampling from each flask was desired; therefore, the design shown in Fig. 5.1.2 was used. In this concept, the evacuated sample port is opened to the reaction flask until equilibrium between the flask and the port is obtained. The port is then closed to the flask and sampled by passing argon and hydrogen carrier gases through the port. To facilitate the procedure, one of. the straight through ports in each of the two three-way stopcock plugs was sealed with epoxy; so, the plugs contained two right angle ports.

\section{Bubbler system}

The reaction flasks were sampled periodically with the bubbler system shown in Fig. 5.1.3. This system contained two sets of bubblers in series which were separated by a copper oxide furnace. Each bubbler, made from a $50 \mathrm{ml}$ dry gas wash bottle whose inlet was fitted with a gas dispersion tip or frit, was initially filled with approximately $25 \mathrm{~g}$ of distilled water. In this system the tritium oxide and tritium gas are transported from the sampling port by a calibrated flow mixture of argon and hydrogen carrier gases. The tritium oxide is trapped in the first series of bubblers because of its high solubility in water. Tritium gas, however, passes through the first series of bubblers into the copper oxide furnace heated to $650^{\circ} \mathrm{F}$ where it is oxidized prior to collection in the second series of bubblers: The bubbler solutions were analyzed for tritium by the Analytical Chemistry Division at ORNL.

Several investigators have studied the trapping efficiency for

tritium oxide vapor and tritium gas in similar bubbler systems. $(37,38)$ 


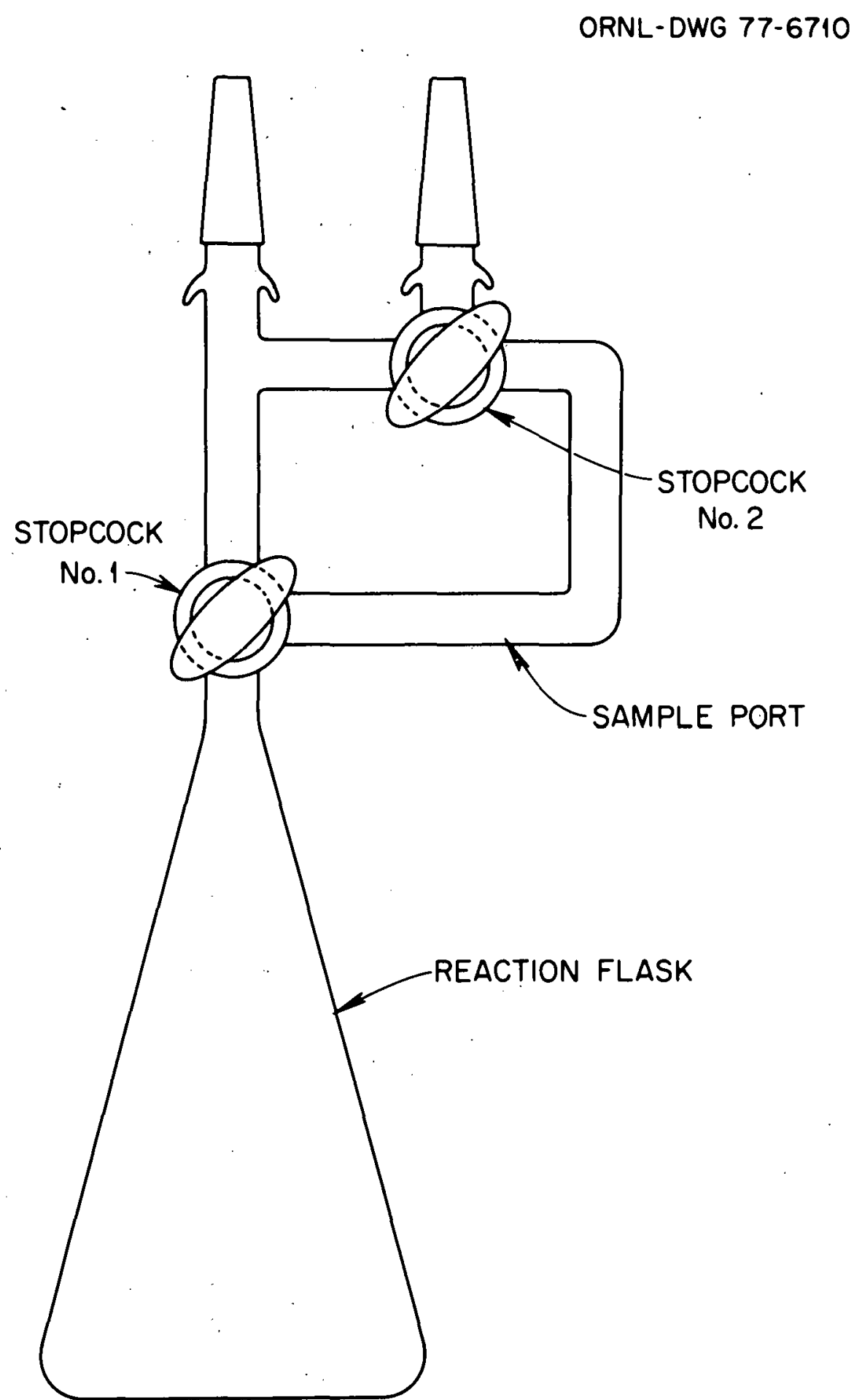

Fig. 5.1.2. Reaction flask with sampling port. 
ORNI DWG 77-7896

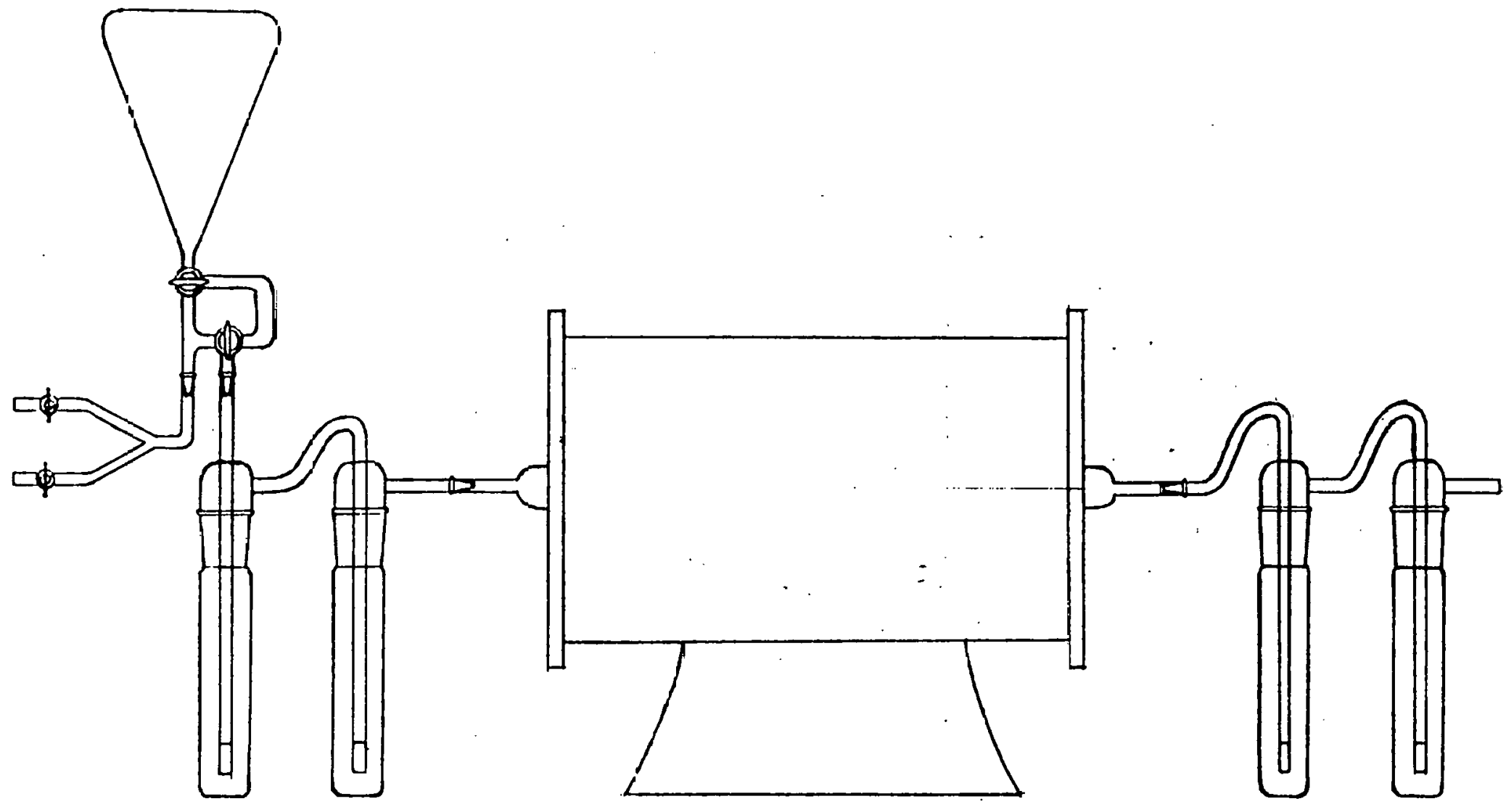

Fiq. 5.1.3. Bubbler system for sampling reaction flasks. 
Theoretically, the overall collection efficiency for a bubbler depends on the initial mass of distilled water in the bubbler, the total gas volume passing the system, the flowrate of gas through the bubbler, the humidity of the effluent gas stream, the water temperature, and the intrinsic trapping efficiency of the bubbler solution. Osborn (37) reports that the overall efficiency of the bubbler depends primarily on its intrinsic efficiency and the humidity of the effluent gas stream. Furthermore, the intrinsic efficiency is sufficiently independent of the water mass and flow rate for most practical purposes where the flow rate is less than 10 liters per minute and the water volume is greater than $50 \mathrm{ml}$. (37) This is especially true for fritted bubblers. It is assumed that the intrinsic efficiency is unity for practical air flow rates $(<100 \mathrm{ml} / \mathrm{min})$, temperatures, and bubbler types. High collection efficiencies $(>90 \%)$ for bubblers have also been reported by Valentine ${ }^{(38)}$ for initial volumes of 30 to $50 \mathrm{ml}$. Thus, for two bubblers in series, the collection efficiency should be greater than $99 \%$ precluding the need for a correction factor.

Valentine ${ }^{(38)}$ also determined the overall collection efficiency for tritium gas. The collection efficiency was less than $0.1 \%$ in every trial and generally between 0.02 and $0.03 \%$.

\section{Calibration of flow gauges}

The initial undertaking in the experiment was to calibrate the flow gauges used to monitor. the flow of the argon and hydrogen carrier gases through the bubbler system. A wet test meter was used in the procedure. The wet test meter was leveled, and the desired gas line was connected to the intake. After the meter was zeroed, various volumes of gas, 
depending on the flow rate, were passed through. The duration of the pass, the barometric pressure, the temperature, and the flow meter reading were recorded. By assuming that the argon and hydrogen gases were ideal, the flow rates at $45.0 \mathrm{~cm} \mathrm{Hg}$ and $20.0^{\circ} \mathrm{C}$ could be calculated by

$$
\bar{V}=\frac{\bar{V}_{e x}\left(P_{c m ~ H g}\right)\left(293^{\circ} \mathrm{K}\right)}{(45.0 \mathrm{~cm} \mathrm{Hg})\left(\mathrm{T}^{\circ} \mathrm{K}\right)}
$$

where $\bar{V}$ is the average flow rate at $45.0 \mathrm{~cm} \mathrm{Hg}$ and $20.0^{\circ} \mathrm{C}, \bar{V}_{\text {ex }}$ is the average flow rate at experimental conditions, $\mathrm{p}$ is the barometric pressure in centimeters of mercury, and $T$ is the temperature in degrees Kelvin during the experiment.

Determination of furnace temperature

The voltages applied across the copper oxide furnace and the uranium trap furnace were controlled by separate variable transformers. Calibrations were made for both furnaces by plotting temperature readings, taken with a chromel-alumel thermocouple, as a function of applied voltages.

\subsection{Procedure}

\section{Flask preparation procedure}

The reaction flasks were initially evacuated to a pressure of $1.0 \times 10^{-5}$ torr. The liquid nitrogen trap was then filled, and the uranium trap furnace was heated to $110^{\circ} \mathrm{C}$. Next, the vacuum system was made static by closing the system to the vacuum pumps, and the pressure increase as a function of time was recorded giving an outgassing curve. 
The manifold was then reevacuated to $1.0 \times 10^{-5}$ torr, made static, and the uranium trap was opened to the system and heated to drive the tritium from the trap." This accomplished, the furnace was removed from the trap allowing the trap to cool and resorb the excess tritium. When the desired pressure was obtained, the glass manifold was isolated from the nitrogen trap and metal manifold, and the excess tritium in the liquid nitrogen trap and the metal manifold was resorbed by the uranium trap. The uranium trap was then closed to the vacuum system.

The flasks were then removed from the glass manifold and backfilled to approximately atmospheric pressure with either dry or moist air. For the dry: air run, commercial, compressed dry air was passed through a flow.meter, a Drierite drying column (which dries air to a dew point of $-100^{\circ} \mathrm{F}$ for pressures up to $90 \mathrm{psig}$ and flows up to 200 liters per hour) and an oild bubbler before entering the flask. The moist air was obtained by passing the commercial compressed dry air through a series of two water bubblers before entering the flask. The bubblers and the flow meter indicated when the pressure was approximately atmospheric. The time at which the flask was backfilled was taken to be the beginning time for the reaction.

Flask preparation for the soil run

The reaction flasks were filled with $200 \mathrm{~g}$ of finely divided clay soil. The flasks were then placed on the vacuum system and evacuated to $1.0 \times 10^{-5}$ torr. The soil was dried and sterilized by heating the flask with a heater gun (nozzle temperature of $500^{\circ} \mathrm{C}$ ) while evacuating the flasks. After a pressure of $1.0 \times 10^{-5}$ torr was achieved, the flasks were prepared using the same procedure as in the dry air run. 
Sampling procedure

After backfilling, the flasks were allowed to equilibrate at least one hour before the initial sampling. The initial samples were then taken as soon after that as possible. Subsequent samples were taken daily. To take a sample, the reaction flask was placed in a flask holder (see Fig. 5.1.3) with the sample port opened to the reaction flask and closed to the surroundings. The exposed portals of the flask were then purged with argon for at least one-half hour. After the purge, the bubbler system was assembled, and the flask was placed on the system. The sample port was then opened to the argon carrier gas stream for one hour at a rate of approximately $80 \mathrm{ml} / \mathrm{min}$. At the end of this time, hydrogen gas flowing at a rate of approximately $40 \mathrm{~m} \ell / \mathrm{min}$ was passed through the port along with the argon carrier gas for an additional hour. The hydrogen gas was added to exchange with any tritium that might be adsorbed on the sampling port wails. The hydrogen gas fluw was llien terminated, and the argon was continued for one more hour. The bubblers were then removed, and the solutions in each series of traps were mixed. The sample port was rinsed with a known volume of distilled water which was added to the solution obtained from the first series of traps. The solutions were labeled and analyzed for tritium concentration by liquid scintillation tcchniques.

\section{Cleaning procedures}

Following each sampling procedure, the bubblers were cleaned to reduce the cross contamination in subsequent runs. The Apiezon-N stopcock grease was washed from the bubbler system glassware with trichloroethylene. The glassware was then rinsed with acetone, rinsed twice with 
distilled water, and rerinsed with acetone before being dried in a tube furnace. The bubbler frits were rinsed with acetone and distilled water before being dried in the same manner. Background samples were then taken before the bubblers were reused to determine the extent of residual contamination.

The sample port was cleaned following each sampling by rinsing with acetone. It was then connected to the glass manifold and evacuated to $1.0 \times 10^{-4}$ torr before being opened to the reaction flask. The purpose of this evacuation was to remove any residual tritium oxide from the sample port walls, to prevent the introduction of contaminants, such as moisture, into the reaction flasks, and to provide a driving force for equilibrium between the tritium in the flask and the sample port. Between runs, the reaction flasks were cleaned before evacuation. Following the last sampling of a. mun, the two reaction flask stopcocks were removed, and the Apiezon-N stopcock grease was removed by washing with trichloroethylene. The flask and its port were rinsed with distilled water and acetone and dried with a heat gun. Samples of rinse water were analyzed to determine the extent of residual contamination. The stopcocks were then regreased and assembled, and the flasks were evacuated to $1 \times 10^{-5}$ torr in preparation for the subsequent run.

\subsection{Experimental Results}

Data

The self-radiation induced conversion of tritium to tritium oxide was observed in a dry air environment, a dry air environment with $200 \mathrm{~g}$ of finely divided soil added to the flasks, and a moist air environment. 
Two runs were made in each environment. Data for these runs are given in Tables 5.3.1 through 5.3.3.

Determination of the initial tritium concentration. The initial tritium concentrations can be derived from the measurements of the tritium gas concentration since the tritium oxide concentrations are neglible in comparison. The measured gas concentrations were averaged to obtain the best estimate of the initial gas concentration. Measurements that differed from the average by more than a factor of 2.5 were discarded in the averaging process. These calculations resulted in the following estimates of the initial concentrations: (1) run 1 for the conversion in a dry air atmosphere, $0.31 \pm 0.15 \mu \mathrm{Ci} / \mathrm{ml}$; (2) run 2 for the conversion in a dry air atmosphere, $0.15 \pm 0.08 \mu \mathrm{Ci} / \mathrm{ml}$; and (3) run 2 for the conversion in a dry air atmosphere in the presence of soil, $0.45 \pm 0.02$ $\mu \mathrm{Ci} / \mathrm{ml}$. 'l'he measurements of the water concentrations for run 1 for the conversion in a dry air atmosphere in the presence of soil were so scattered that the run was disregarded in further analyses.

A general trend of a decrease in the tritium gas concentration as a function of time occurred in the moist air run. To determine the initial tritium concentration, the tritium gas concentration was plotted against time and then extrapolated to time, $t=0$. The values were $45 \pm 6 \mu \mathrm{Ci} / \mathrm{ml}$ for run 1 and $38 \pm 4 \mu \mathrm{Ci} / \mathrm{ml}$ for run 2 .

Tests were made to determine if the initial concentrations for runs 1 and 2 for the conversion of tritium in dry air and in moist air were statistically different. In both cases the difference was not significant; therefore, the concentrations for the two runs were averaged and data from the runs were combined. Thus, the initial concentration for 
Table 5.3.1. Data for dry air atmosphere

\begin{tabular}{|c|c|c|c|c|c|}
\hline $\begin{array}{c}\text { Run } \\
\text { number }\end{array}$ & $\begin{array}{l}\text { Reaction } \\
\text { time } \\
\text { (hr) }\end{array}$ & $\begin{array}{l}{[\mathrm{HTO}]^{a}} \\
\mu \mathrm{Ci} / \mathrm{ml}\end{array}$ & $\begin{array}{l}{\left[\mathrm{T}_{2}\right]^{a} .} \\
\mu \mathrm{Ci} / \mathrm{ml}\end{array}$ & $\begin{array}{l}\text { [HTO }^{b} \\
\mu \mathrm{Ci} / \mathrm{ml}\end{array}$ & $\begin{array}{l}{\left[\mathrm{T}_{2}\right]^{b}} \\
\mu \mathrm{Ci} / \mathrm{ml}\end{array}$ \\
\hline 1 & 1.5 & $3.9 \times 10^{-4}$ & 0.15 & $3.8 \times 10^{-4}$ & 0.15 \\
\hline 1 & 74 & $8.8 \times 10^{-4}$ & $4.8 \times 10^{-3 c}$ & $8.7 \times 10^{-4}$ & $4.8 \times 10^{-3 c}$ \\
\hline 1 & 97 & $6.3 \times 10^{-4}$ & 0.25 & $5.7 \times 10^{-4}$ & 0.25 \\
\hline 1 & 120 & $4.5 \times 10^{-4}$ & 0.48 & $3.2 \times 10^{-4}$ & 0.48 \\
\hline 1 & 144 & $1.2 \times 10^{-3}$ & 0.37 & $1.2 \times 10^{-3}$ & 0.37 \\
\hline 2 & 2.5 & $2.4 \times 10^{-4}$ & $8.8 \times 10^{-2}$ & $2.3 \times 10^{-4}$ & $8.7 \times 10^{-2}$ \\
\hline 2 & 75 & $3.7 \times 10^{-4}$ & $1.0 \times 10^{-2 c}$ & $3.6 \times 10^{-4}$ & $9.8 \times 10^{-3 c}$ \\
\hline 2 & 99 & $1.0 \times 10^{-3}$ & 0.12 & $1.7 \times 10^{-4}$ & 0.11 \\
\hline 2 & 121 & $6.2 \times 10^{-3}$ & 0.12 & $2.9 \times 10^{-3}$ & 0.12 \\
\hline 2 & 144 & $1.2 \times 10^{-3}$ & 0.26 & $1.0 \times 10^{-3}$ & 0.26 \\
\hline
\end{tabular}

$\alpha_{\text {Raw data. }}$

$b_{\text {Corrected for background. }}$

Ciscarded in calculating the initial concentration. 
Table 5.3.2. Data for dry air atmosphere and soil

\begin{tabular}{|c|c|c|c|c|c|}
\hline $\begin{array}{c}\text { Run } \\
\text { number }\end{array}$ & $\begin{array}{l}\text { Reaction } \\
\text { time } \\
\text { (hr) }\end{array}$ & $\begin{array}{l}\text { [HTO }^{a} \\
\mu \mathrm{Ci} / \mathrm{ml}\end{array}$ & $\begin{array}{l}{\left[\mathrm{T}_{2}\right]^{a}} \\
\mu \mathrm{Ci} / \mathrm{ml}\end{array}$ & $\begin{array}{l}\text { [HTO }^{b} \\
\mu \mathrm{Ci} / \mathrm{ml}\end{array}$ & $\begin{array}{c}{\left[\mathrm{T}_{2}\right]^{b}} \\
\mu \mathrm{Ci} / \mathrm{m} \ell\end{array}$ \\
\hline 1 & 1.5 & $2.1 \times 10^{-3}$ & 4.1 & $2.8 \times 10^{-4}$ & 4.1 \\
\hline 1 & 24 & $3.9 \times 10^{-3}$ & $4.7 \times 10^{-1}$ & $2.8 \times 10^{-3}$ & $4.7 \times 10^{-1}$ \\
\hline 1 & $4 \%$ & $1.4 \times 10^{=7}$ & 0.0 & $3.0 \times 10^{-5}$ & 0.0 \\
\hline 1 & 68 & $1.5 \times 10^{-3}$ & $5.6 \times 10^{-1}$ & $-1.2 \times 10^{-4}$ & $5.6 \times 10^{-1}$ \\
\hline 1 & 94 & $1.4 \times 10^{-3}$ & 7.1 & $-3.2 \times 10^{-4}$ & 7.1 \\
\hline 1 & 166 & $2.5 \times 10^{-3}$ & 6.7 & $1.3 \times 10^{-3}$ & 6.7 \\
\hline 2 & 1.1 & $3.2 \times 10^{-3}$ & $3.2 \times 10^{-1}$ & $4.6 \times 10^{-4}$ & $3.2 \times 10^{-1}$ \\
\hline 2 & 19 & $3.1 \times 10^{-3}$ & $5.1 \times 10^{-1}$ & $2.1 \times 10^{-3}$ & $5.1 \times 10^{-1}$ \\
\hline 2 & 90 & $3.2 \times 10^{-3}$ & $4.9 \times 10^{-1}$ & $1.3 \times 10^{-3}$ & $4.9 \times 10^{-1}$ \\
\hline 2 & 114 & $4.4 \times 10^{-3}$ & $2.9 \times 10^{-2^{c}}$ & $2.2 \times 10^{-3}$ & $2.7 \times 10^{-2 c}$ \\
\hline 2 & 138 & $4.2 \times 10^{-3}$ & $4.7 \times 10^{-1}$ & $2.8 \times 10^{-3}$ & $4.7 \times 10^{1}$ \\
\hline
\end{tabular}

$a_{\text {Raw data. }}$

$b_{\text {Corrected for background. }}$

Discarded in calculating the initial concentration. 
Table 5.3.3. Data for moist air atmosphere

\begin{tabular}{|c|c|c|c|c|c|}
\hline $\begin{array}{c}\text { Run } \\
\text { number }\end{array}$ & $\begin{array}{l}\text { Reaction } \\
\text { time } \\
\text { (hr) }\end{array}$ & $\begin{array}{l}{[\mathrm{HTO}]^{a}} \\
\mu \mathrm{Ci} / \mathrm{ml}\end{array}$ & $\begin{array}{l}{\left[\mathrm{T}_{2}\right]^{\alpha}} \\
\mu \mathrm{Ci} / \mathrm{m} \ell\end{array}$ & $\begin{array}{l}{[\mathrm{HTO}]^{b}} \\
\mu \mathrm{Ci} / \mathrm{ml}\end{array}$ & $\begin{array}{l}{\left[\mathrm{T}_{2}\right]^{b}} \\
\mu \mathrm{Ci} / \mathrm{m} \ell\end{array}$ \\
\hline 1 & 2.0 & $1.7 \times 10^{-2}$ & 8.3 & $8.1 \times 10^{-3}$ & 8.3 \\
\hline 1 & 23 & $5.1 \times 10^{-2}$ & 39 & $3.5 \times 10^{-2}$ & 39 \\
\hline 1 & 47 & $5.3 \times 10^{-2}$ & 51 & $4.4 \times 10^{-2}$ & 51 \\
\hline 1 & 71 & $4.3 \times 10^{-2}$ & 19 & $1.8 \times 10^{-2}$ & 19 \\
\hline 1 & 142 & $6.3 \times 10^{-2}$ & 17 & $5.9 \times 10^{-2}$ & 17 \\
\hline 1 & 164 & $1.1 \times 10^{-1}$ & 19 & $9.0 \times 10^{-2}$ & 19 \\
\hline 2 & 1.1 & $1.2 \times 10^{-2}$ & 38 & $6.3 \times 10^{-3}$ & 38 \\
\hline 2 & 22 & $3.3 \times 10^{-2}$ & 35 & $2.0 \times 10^{-2}$ & 35 \\
\hline 2 & 46 & $4.1 \times 10^{-2}$ & 32 & $2.5 \times 10^{-2}$ & 32 \\
\hline 2 & 72 & $4.4 \times 10^{-2}$ & 18 & $2.7 \times 10^{-2}$ & 18 \\
\hline 2 & 142 & $2.4 \times 10^{-1}$ & 23 & $2.4 \times 10^{-1}$ & 23 \\
\hline 2 & 164 & $6.8 \times 10^{-2}$ & 24 & $4.7 \times 10^{-1}$ & 24 \\
\hline
\end{tabular}

$a_{\text {Raw data. }}$

$b_{\text {Corrected for background. }}$ 
the conversion of tritium to tritium oxide in a dry air atmosphere is $0.22 \mu \mathrm{Ci} / \mathrm{ml}$ while that for the conversion in a moist air atmosphere is $43 \mu \mathrm{Ci} / \mathrm{ml}$. The initial concentration for the conversion in dry air in the presence of soil remains at $0.45 \mu \mathrm{Ci} / \mathrm{ml}$.

Determination of the reaction rate constant. The reaction rate constant was determined by assuming that the following relationships

$$
\begin{aligned}
& R_{0}=-\frac{\left.d[1]^{2}\right]_{u}}{d t}=k_{2}\left[T_{2}\right]_{0}^{\overline{2}} \\
& R_{t}=-\frac{d\left[T_{2}\right]}{d t} k_{2}\left[T_{2}\right]_{0}\left[T_{2}\right] .
\end{aligned}
$$

are valid over the range of initial tritium concentrations used in this experiment. In these equations, $\mathrm{R}$ is the reaction rate, $\left[\mathrm{T}_{2}\right]$ is the concentration of tritium in the gaseous form, $k_{2}$ is the second order reaction rate constant, $t$ is the time, and " $o$ " indicates initial conditions. Equation 5.3.1 has been established experimentally for initial tritium concentrations between $10^{-2}$ and $1 \mathrm{mCi} / \mathrm{ml}$; equation 5.3 .2 has not yet been verified. If equation 5.3 .1 is valid, however, equation 5.3.2 should be a good approximation for the small reaction-yields observed in the experiment since $\left\lceil\mathrm{T}_{2}\right\rceil$ is nearly constant and equal to $\left[\mathrm{T}_{2}\right]_{0}$

It is desired to transform equation 5.3.2 into an equation containing the concentration of tritium as tritiated water (denoted [HTO]). Assuming that tritiated water is the only significant product, the total tritium concentration is equal to the concentration of tritium present as tritiated water plus the concentration of tritium present as tritium 
gas (denoted $\left[\mathrm{T}_{2}\right]$ ). This in turn is equal to the initial tritium $:$ concentration (denoted [IC]) if radioactive decay is neglected. Thus,

$$
[\mathrm{IC}]=[\mathrm{HTO}]+\left[\mathrm{T}_{2}\right]=\text { constant } .
$$

It follows that:

$$
\left[\mathrm{T}_{2}\right]=[\mathrm{IC}]-[\mathrm{HTO}]
$$

So that,

$$
\left[\mathrm{T}_{2}\right]_{0}=[\mathrm{IC}]-[\mathrm{HTO}]_{\mathrm{O}},
$$

and

$$
\frac{\mathrm{d}\left[\mathrm{T}_{2}\right]}{\mathrm{dt}}=-\frac{\mathrm{d}[\mathrm{HTO}]}{d t} \text { since }[\mathrm{IC}]=\text { constant. }
$$

Substituting these into equation 5.3 .2 gives:

$$
\frac{\mathrm{d}[\mathrm{HTO}]}{\mathrm{dt}}=\mathrm{k}_{2}\left\{[\mathrm{IC}]-[\mathrm{HTO}]_{0}\right\}\{[\mathrm{IC}]-[\mathrm{HTO}]\} .
$$

Equation 5.3 .3 can be solved yielding:

$$
[\mathrm{IC}]-[\mathrm{HTO}]=\mathrm{Ke}^{-\mathrm{k}_{2} \mathrm{Kt}} \text {, }
$$

where

$$
K=[\mathrm{IC}]-[\mathrm{HTO}]_{0} \cdot
$$

Taking the natural logarithm of both sides of equation 5.3 .4 gives

$$
\ln \{[\mathrm{IC}]-[\mathrm{HTO}]\}=\ln \mathrm{K}-\mathrm{k}_{2} \mathrm{Kt}
$$


Therefore, the natural logarithm of the initial concentration minus the concentration of tritium present as tritiated water is a linear function with respect to time. This function was fit by the linear least squares regression technique giving the slope, $m$, and the $y$ intercept. The second order reaction rate constant could then be obtained from the slope by;

$$
k_{2}=\frac{m}{-K}=\frac{m}{-\left\{\lceil\Gamma \mathrm{C}]-\left\lceil\mathrm{HIO}_{0}\right\}\right.} \approx \frac{\mathrm{m}}{-\lceil\mathrm{IC}\rceil} \text {. }
$$

As mentioned previously, the second order reaction rate constants were calculated based on the assumption that the initial reaction rate is proportional to the square of the initial tritium concentration. Casaletto et al. (32) found that this relationship holds for initial tritium concentrations between $10^{-2}$ and $3.0 \mathrm{mCi} / \mathrm{ml}$. Dorfman and Hemmer (31) studied the reaction at higher initial tritium concentrations $(90-340$ $\mathrm{mCi} / \mathrm{m} l)$ and concluded that the reaction rate in this range is proportional to the initial concentration. On the other hand, Belovodskil et al. (33) found that over a range of $9.0 \times 10^{-2}$ to $90 \mathrm{mCi} / \mathrm{ml}$ the initial reaction rate is proportional to the initial tritium concentration raised to the $5 / 3$ power. This range includes most of the initial concentrations used by Casaletto et al. ${ }^{(32)}$ and the beginning of the range used by Dorfiman and Hemmer. (31)

It is also assumed that Casaletto et al.'s (32) argument expanding the second order dependence of the initial reaction rate on the initial tritium concentration to the dependence of the reaction rate at time $t$ on the initial tritium concentration and the concentration at time $t$ is valid. A large error should not be introduced by this assumption 
since the reaction was observed only in the initial phases so that $\left[\mathrm{T}_{2}\right]_{t}$ is not very different from $\left[\mathrm{T}_{2}\right]_{0}$.

The second order reaction rate constants that were obtained for the dry air run, the dry air run in the presence of soil, and the moist air run are given in Table 5.3.4 along with the initial tritium concentrations.

Table 5.3.4. Reaction rate constants

\begin{tabular}{|c|c|c|}
\hline $\begin{array}{c}\text { Initial tritium } \\
\text { concentration } \\
(\mu \mathrm{Ci} / \mathrm{ml})\end{array}$ & Reaction environment & $\begin{array}{c}\text { Reaction rate } \\
\text { constant } \\
(\mathrm{ml} / \mathrm{mCi}-\mathrm{hr})\end{array}$ \\
\hline 0.22 & tritium in dry air & $9.5 \times 10^{-2}$ \\
\hline 0.45 & $\begin{array}{c}\text { tritium in dry air } \\
\text { in presence of } \\
\text { sterile soil }\end{array}$ & $5: 0 \times 10^{-2}$ \\
\hline 43 & tritium in moist air & $4.0 \times 10^{-4}$ \\
\hline
\end{tabular}

Discussion. A rather large fluctuation in the data was noted. This is not due to the random error associated with radioactive decay since the standard deviation due to counting was generally less than $5 \%$ and usually less than $3 \%$ in determinations of the HTO concentrations and always less than $1 \%$ in determinations of the HT gas concentrations. Therefore, the fluctuations are attributed to errors in the sampling procedure:

Several sources of error may be present. The major ones appear to be: (1) leaks in the bubbler system; (2) incomplete conversion of tritium gas within the copper oxide; and (3) cross contamination between samplings . 
Leaks in the bubbler system can bias measurements of the tritium gas concentration or both measurements of the tritium oxide and tritium gas concentrations. A leak preceding the first series of bubblers would cause isolated incidences where both the tritium oxide and tritium gas concentrations appear to be low. Examples of such an occurrence can be seen in the samples taken at 1.1 hours of run 2 using a dry air environment in the presence of sterile soil and at 2.0 and $71 \mathrm{hr}$ of run 1 using a mọst air environment. A leak following the first series of bubblers or incomplete conversion within the copper oxide furnace could cause isolated incidences where only the tritium gas concentrations would be low. Possibilities for this are at $74 \mathrm{hr}$ in run 1 and $75 \mathrm{hr}$ in run 2 of the dry air run, at $114 \mathrm{hr}$ in run 2 of the dry air run in the presence of sterile soil, and at $72 \mathrm{hr}$ in run 2 of the moist air run.

Cross contamination between samples due to adsorptiun of lrilium oxide and tritium gas on the walls of the sample port and adsorption of tritium oxide on the walls of the water trap could also have biased the data. Evidence of such a bias is the increase in the tritium concentration over time in the dry air runs. An estimate of the cross contamination due to water bubbler carry over was made by assembling the bubblers as if taking a sample, allowing the assembled bubbler to stand for approximately $5 \mathrm{~min}$, disassembling the bubbler and analyzing the trap water for tritium. The result was used as a background correction for the sample measurement. This procedure, however, did not improve the results.

One other type of bias should be mentioned. In the bubbler system used to separate tritium oxide from tritium gas, the collection of 
tritium oxide, as discussed in the equipment section, is very efficient. Collection of tritium gas is very inefficient. However, if the tritium gas content is much greater than the oxide, inefficient collection of the gas could strongly increase the tritium trapped as oxide. A collection efficiency of $0.02 \%$ for the collection of tritium gas (reported by Valentine (38), would account for all the tritium collected as tritium oxide. The observed reaction rate would then be higher than the actual rate.

Because of the possibility of sample bias and the uncertainty in the assumptions used in the calculations, little confidence should be placed in the exact numerical results of the present experiment. Nevertheless, the general implications of the results are important.

Tritium oxidation in a dry air atmosphere

Since the initial concentrations were not significantly different, the data was combined to calculate the second order reaction rate constant and the initial tritium concentration. This resulted in an initial tritium concentration of $0.22 \mu \mathrm{Ci} / \mathrm{ml}$ and a second order reaction rate constant of $9.5 \times 10^{-2} \mathrm{ml} / \mathrm{mCi}-\mathrm{hr}$. This rate constant is somewhat higher than the $6.2 \times 10^{-4} \mathrm{ml} / \mathrm{mCi}-\mathrm{hr}$ rate constant determined by Casaletto et al., (32) but the initial tritium concentration is significantly less than the $10^{-2}$ to $3.0 \mathrm{mCi} / \mathrm{m} \ell$ range they investigated. This indicates that tritium gas could very well be converted to tritium oxide more rapidly at lower initial tritium concentrations in a dry air environment than would be predicted by an extrapolation of the data of Casaletto et al. (32) (see Figure 5.3.1). Since tritium oxide is more hazardous than tritium gas, it follows that a tritium gas release at lower 


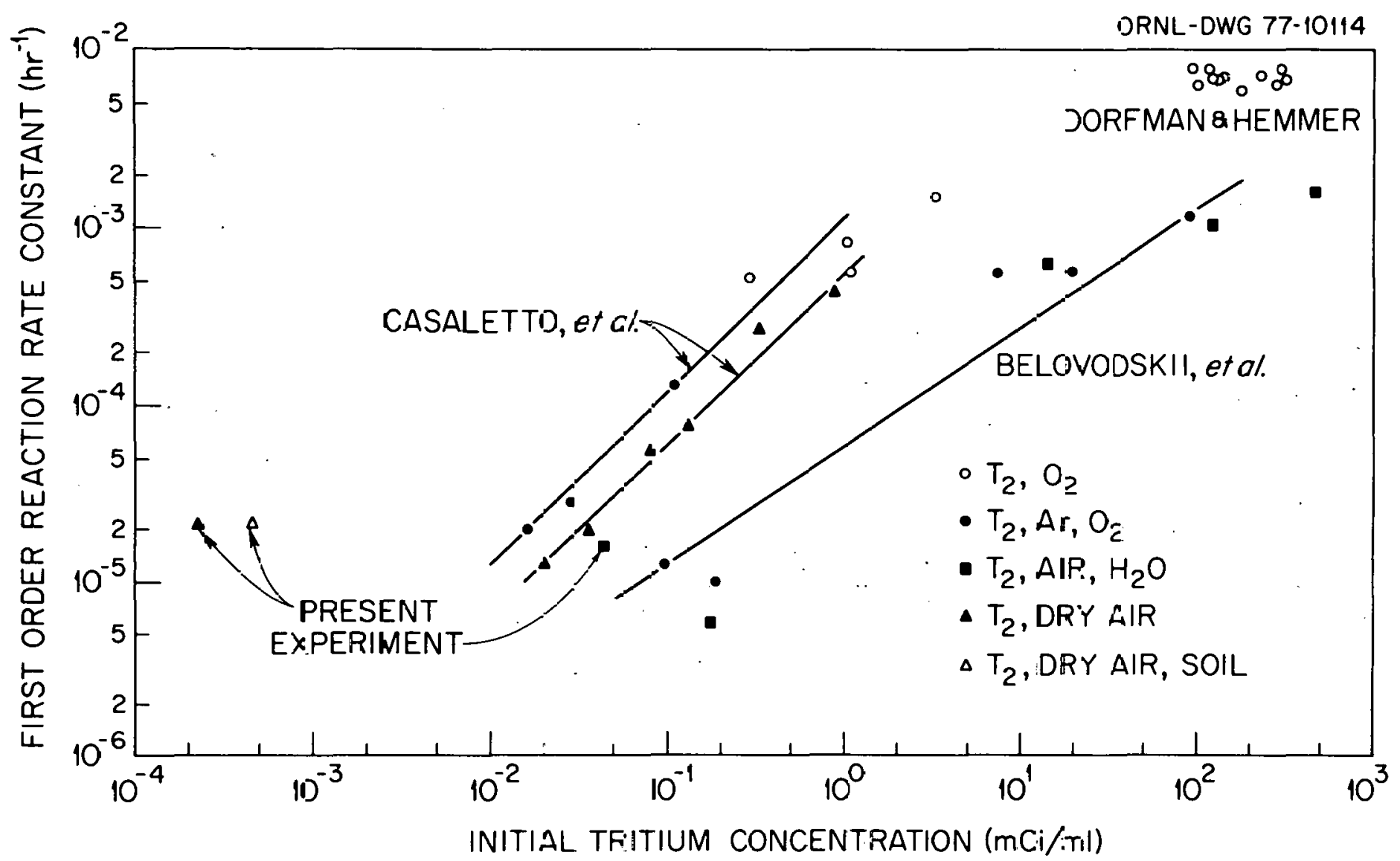

Fig. 5.3.1. First order reaction rate constant as a function of the iritial tritium concentration. 
concentrations is more hazardous than would be predicted by the extrapolation of previous data.

Tritium oxidation in dry air atmosphere in presence of soil

Two initial tritium concentrations were used to study the oxidation of tritium in the presence of soil for a dry air atmosphere. The two concentrations were $0.45 \mu \mathrm{Ci} / \mathrm{ml}$ and $4.2 \mu \mathrm{Ci} / \mathrm{ml}$. The samples collected for the $4.2 \mu \mathrm{Ci} / \mathrm{ml}$ initial concentration were apparently too inconsistent to allow the determination of the second order reaction rate constant, but for the $0.45 \mu \mathrm{Ci} / \mathrm{ml}$ initial tritium concentration this constant was determined to be $5.0 \times 10^{-2} \mathrm{ml} / \mathrm{mCi}-\mathrm{hr}$. This value is less than $9.5 \times 10^{-2}$ $\mathrm{m} \ell / \mathrm{mCi}-\mathrm{hr}$ which was found for the oxidation of tritium in dry air. In the dry air mun in the presence of soil the initial tritium concentration was slightly larger than for the tritium in dry air experiments. The. effect of the difference in: concentrations apparently overshadows any effect the soil may have on the oxidation rate. Experiments therefore, allowing greater control of the initial tritium concentration are needed to determine any effect the soil may have on the reaction rate.

Conversion of tritium to tritium oxide in a moist air environment

The best estimate of the second order reaction rate constant is obtained by combining the data for the two runs since their initial tritium concentrations were not significantly different. This gave an initial concentration of $43 \mu \mathrm{Ci} / \mathrm{ml}$ which is within the range investigated by Casaletto et al. (32) (oxidation) and Yang and Gevantman ${ }^{(34)}$ (isotopic exchange). Condensation of the moisture in the reaction flasks occurred due to a drop in ambient temperatures from $21^{\circ} \mathrm{C}$ to as $10 \mathrm{w}$ as $11^{\circ} \mathrm{C}$ for 
run 1 and from $12^{\circ} \mathrm{C}$ to as 1 ow as $2^{\circ} \mathrm{C}$ for run 2 . Therefore, correction was made for condensation assuming: (1) that $100 \%$ humidity was obtained during backfilling, (2) tritiated water behaves like ordinary water, (3) thermodynamic equilibrium is established within the reaction flasks, and (4) thermal equilibrium is established between the flasks and the surroundings. The second order rate constant, $3.95 \times 10^{-4} \mathrm{ml} / \mathrm{mCi}-\mathrm{hr}$, obtained from such an analysis is in good agreement with the rate constants reported by Casaletto et al. (32) which were, however, made with tritium in dry air.

The results of the moist air run are difficult to interpret for several reasons. First, it was expected that the conversion rate would proceed by isotopic exchange as well as by its own $\beta$-radiation induced oxidation. In this case the conversion rate could be obtained by the superposition of the rate for self-induced oxidation and the rate for isotopic exchange. Results of the present experiment do not support this since the conversion rate was approximately equal to that obtained by Casaletto et al. (32) in a dry air atmosphere. Previous measurements of the reaction rate in a moist environment have given conflicting results. One found the conversion rate in moist oxygen to be approximately 3 times that for the self-oxidation of tritium in oxygen, (32) a rate that is slightly larger than that obtained by the superposition of the oxidation and exchange rates. Another compared the conversion rate of tritium in a moist air environment ( $50 \%$ humidity) with the conversion rate in an argon-oxygen mixture ( $20 \%$ oxygen) and found that the rates are approximately equal for equivalent tritium concentrations. (33) In the latter experiment, the rate varied with the $5 / 3$ power of the initial tritium concentration rather than with the second power of the initial tritium 
concentration as found by Casaletto et al. (32) In addition to these difficulties, the decrease in the total tritium in the sampling port is as yet unexplained. 


\section{RECOMMENDATIONS AND CONCLUSIONS}

\subsection{Recommendations}

The results of this experiment pointed out some changes in the experimental procedures that need to be made to improve the accuracy of the data. First a tighter vacuum system made of stainless steel and glass could be used to decrease outgassing and inleakage, allowing more accurate pressure measurements. It 15 also believed thal belles contioul of the initial tritium concentration can be achieved by filling a small evacuated volume to the desired pressure with tritium and then expanding this into the evacuated reaction flasks. The final pressure, and thus the initial tritium concentration, can be calculated from the known volume ratio. This procedure has the advantages that: (1) the measured tritium pressure will be so large that outgassing should be neglible, and (2) the tritium pressure should be within the range of pressure measuring instruments accurate to five significant figures.

Because of the possibility that tritium gas trapping in water bubblers biases the measurement of tritium oxide, separation of the tritium oxide from the tritium gas could be achieved by liquid nitrogen traps. A series of two traps followed by a copper oxide furnace and another series of two traps would be desirable. Separate sampling of each trap in a series would allow an estimation of the erap efficiency. Measurements made by this sampling system could also be compared to identical samples taken on a water bubbler sampling system.

Cross contamination between samples could be reduced by taking only one sample per reaction flask. In this case the whole reaction flask 
would be sampled. Care would be required to insure that each reaction flask initially contains the same tritium concentration and that the flasks are backfilled identically. This procedure would also eliminate bias due to failure to obtain equilibrium between sample port and reaction flask and bias due to the constant reduction of the tritium concentration over time as samples are taken. A more ideal situation would be a common reaction flask containing a number of sampling ports. This would insure identical initial tritium concentrations and reaction environments while retaining the advantages listed above. However, the size of each port that would be required to detect the tritium makes this impractical. Elimination of cross contamination in the sampling system requires that a clean sampling system always be used. Because of the price of traps, a trial of the cleaning procedure given by Casaletto et al. (32) is recommended.

It is believed that the above changes in the experimental procedure will drastically enhance the accuracy of the data. Once the data is adequate, the following investigations are recommended. First, the functional dependence of the initial reaction rate on the initial tritium concentration should be determined for the oxidation of tritium in dry air. The initial tritium concentration of $10^{-2}$ to $300 \mathrm{mCi} / \mathrm{ml}$ should be covered. In addition the reaction rate constant should be determined. Next the investigation should be extended to lower initial tritium concentrations. Following this the influence of water vapor on the reaction rate should be determined over this extended range. Then a study of the influence of atmospheric pollutants on the reaction rate can be undertaken. 


\subsection{Summary and Conclusions}

A determination of the reaction rate constant for the oxidation of tritium in dry air indicated that the reaction rate is faster than would be predicted by extrapolation of the data of Casaletto et al. (32) The determination of the reaction rate in dry air in the presence of sterile soil indicated that any effect that the sterile soil has on the reaction rate is small. The results of the moist air run are difficult to interpret at this time. "More data is needed to quantity the reaction rate at low initial tritium concentrations, quantify the effect of soll on the reaction rate, determine the effect of moisture on the reaction rate, and determine the true functional dependence of the initial reaction rate on the initial tritium concentration. Close scrutiny of the data indicates procedural changes that can improve the accuracy of subsequent experiments; these are given in the previous section. 


\section{REFERENCES}

1. Radiological Health Handbook, Revised Edition, U.S. Dept. of Health, Education and Welfare, Rockville, Maryland, Jan., 1970.

2. D. G. Jacobs, "Sources of Tritium and Its Behavior upon Release to the Environment," TID-24635, USAEC Division of Technical Information Extension, Oak Ridge, Tn., Dec., 1968.

3. R. V. Osborne, "Permissible Levels of Tritium in Man and the Environment," Radiat. Res. 50, 197-211 (1972).

4. E. A. Pinson and W. H. Langham, "Physiology and Toxicology of Tritium in Man," J. App. Physiol. 10, 108-126 (1957).

5. J. W. Elwood, "Ecological Aspects of Tritium Behavior in the Environment," Nucl. Saf. 22, 326-337 (1971).

6. C. W. De Long, R. C. Thompson, and H. A. Kornberg, "Percutaneous Absorption of Tritium Oxide," Am. J. Roent. 71, 1038-1045 (1954).

7. E. A. Pinson, "Water Exchanges and Barriers as Studied by Use of Hydrogen Isotopes," Physiol. Rev. 32, 123-134 (1952).

8. J. D. Eakins, W. P. Hutchinson, and A. E. Lally, "The Radiological Hazard from Tritium Sorbed on Metal Surfaces," Health Phys. 28, 213-244 (1975).

9. W. P. Hutchinson and J. D. Eakins, "The Radiological Hazard from Tritium Sorbed on Metal Surfaces, Part I. The Sorption of Tritium on Brass," AERE-R-5680, Atomic Energy Research Establishment, Harwe11, Berkshire, England, Apr., 1968.

10. J. E. Phillips, C. E. Easterly, and E. L. Compere, "Sources of Tritiun," NucZ. Saf., to be published.

11. J. A. Miske1, "Production of Tritium by Nuclear Weapons," in Tritium, pp. 79-85, ed. by A. A. Moghissi, M. W. Carter, Messenger Graphics, Phoenix, Arizona and Los Vegas, Nevada, May, 1973.

12. M. S. Terpilak, C. L. Weaver, and S. Wieder, "Dose Assessment of lonizing Radiation Exposure to the Population," Kadiol. Health Data Rep. 12, 171-188 (1971).

13. E. Eriksson, "An Account of the Major Pulses of Tritium and Their Effects in the Atmosphere," Tellus 17, 118-130 (1965).

14. "Commercial Power Reactors," in Tritium Control Technology, WASH1269, pp. 381-425, cd. by T. B. Rhinehammer, P. H. Lamberger, 1973.

15. Nuclear Regulatory Commission, Summary of Radioactivity Released in Effluents from Nuclear Power Plants during 1973, NUREG-75/001, 1973. 
16. R. E. Manson and H. E. Smyth, "The NRX Reactor, A General Description," AECL-2692, Chalk River Nuclear Laboratories, Chalk River, Ontario, Feb., 1967.

17. L. E. Trevorrow, B. J. Kullen, R. L. Jarry, and M. J. Steindler, "Tritium and Noble Gas Fission Products in the Nuclear Fuel Cycle," ANL-8102, Argonne National Laboratories, Argonne, Illinois, Oct., 1974 .

18. "Allied-Gulf Nuclear Services," in Tritium Control Technology, WASH-1269, pp. 392-397, ed. by T. B. Rhinehammer, P. H. Lamberger, 1973.

19. "Nuclear Fuel Services," in Tritium Control Technology, WASH-1269, pp. 405-411, ed. by T. B. Rhinehammer, P. H. Lamberger, 1973.

20. B. J. Kullen, L. E. Trovorrow, and M. J. Steindler, "Tritium and Noble-Gas Fission Products in the Nuclear Fuel Cycle II Fuel Reprocessing Plants," ANL-8135, Argonne National Laboratories, Argonne, Illinois, Mar., 1975.

21. E. L. Compere, Oak Ridge National Laboratory, Oak Ridge, Tenn., Personal Communication.

22. W. L. Marter, "Environmental Effects of a Tritium Gas Release from the Savannah River Plant on May 2, 1974," DP-1369, Savannah River Laboratory, Aiken, S.C., Nov., 1974.

23. W. K. Jacobsen, "Environmental Effects of a 'lritium Gas Release from the Savannah River Plant on December 31, 1975," DP-1415, Savannah River Laboratory, Aiken, S.C., Mar., 1976.

24. J. E. Draley and S. Greenberg, "Some Features of the Environmental Impact of a Fusion Reactor Power Plant," in Technology of Controlled Thermonuclear Fusion Experiments and the Engineering Aspects of Fusion Reactors, ed. by E. L. Draper, CONF-721111, 1974.

25. L. D. Hansborough, "Tritium Inventories and Leakages: A Review and Some Additional Considerations," in Technology of Controlled Thermonuclear Fusion Experiments and the Engineering Aspects of Fusion Reactors, CONF-721111, ed. by E. L. Draper, 1974 .

26. T. J. Kabele, A. B. Johnson, and L. K. Mudge, "Definition of Source Terms for Tritium Evolution from CTR Systems," in International Conference on Kadiation Effects and Tritium Technology for Fusion Reactors, pp. 32-57, Vol. 3, CONF-750989, Mar., 1976.

27. K. Nateson and D. L. Smith, "Effectiveness of Tritium Removal from a CTR Lithium Blanket by Cold Trapping Secondary Liquid Metals $\mathrm{Na}$, $\mathrm{K}$, and NaK," Nucl. Technol. 22, 138-150 (1974). 
28. J. E. Draley, V. A. Maroni, T. A. Coultas, and R. A. Krowski, "Environmental Impact Study of a Reference Theta-Pinch Reactor (RTPR)," in Topical Meeting on Technology of Controlled Nuclear Fusion, CONF-740402-P1, 1974.

29. S. C. Lind, "Chemical Action Produced by Radiation Emanation. I. The Combination of Hydrogen and Oxygen," J. Am. Chem. Soc. 41, 531-551 (1919).

30. A. L. Marshal1, "Combination of Hydrogen and Oxygen under the Influence of Cathode Rays," J. Am. Chem. Soc. 50, 3197-3204 (1928).

31. L. M. Dorfman and B. A. Hemmer, "Ion-Pair Yield of the TritiumOxygen Reaction," J. Chem. Phys. 22, 1555-1558 (1954).

32. G. J. Casaletto, L. H. Gevantman, and J. B. Nash, "The Self-Radiation Oxidation of Tritium in Oxygen and Air," USNRDL-TR-565, U.S. Naval Defense Laboratory, San Francisco, California, May 8, 1962.

33. L. F. Belovodskii, V. K. Saevori, V. I. Grishmanovskii, and N. V. Nefedov, "Oxidation of Tritium in Air under the Action of Intrinsic Radiation," Translation from Atomnaya Energiya 38, 379-381 (1975).

34. J. Y. Yang and L. H. Gevantman, "Tritium B-Radiation-Induced Isotopic Exchange with Water Vapor," J. Phys. Chem. 68, 3115-3119 (1964).

35. J. D. Eakins and W. P. Hutchinson, "The Radiological Hazard from the Conversion of Tritium to Tritiated Water in the Air by Metal Catalysts," pp. 392-399, in Tritium, ed. by A. A. Moghissi, M. W. Carter, Messinger Graphics, Phoenix, Arizona and Los Vegas, Nevada, May, 1973.

36. D. H. Ahmann, P. S. Flint, and O. N. Salmon, "Use of Sorbent Beds for Transferring Hydrogen Gases," KAPL-1114, Knolls Atomic Power Laboratory, Schenectady, New York, June 17, 1954.

37. R. V. Osborne, "Sampling for Tritiated Water Vapor," in Third Intemational Congress of the International Radiation Protection Association Meeting, CONF-730907-P2, Washington, D.C., Sept. 9,. 1973.

38. A. M. Valentine, "An Investigation of a Bubbler Tritium System," LA-3916, Los Alamos Scientific Laboratory, Los Alamos, New Mexico, Apr., 1968. 
THIS PAGE

\section{WAS INTENTIONALLY LEFT BLANK}




\author{
ORNL/TM-5963 \\ Dist. Category UC-20,-20e
}

INTERNAL DISTRIBUTION

$\begin{aligned} \text { 1. } & \text { S. I. Auerbach } \\ 2 . & \text { J. A. Auxier } \\ \text { 3. } & \text { G. M. Begun } \\ 4 . & \text { J. T. Bell } \\ 5 . & \text { L. A. Berry } \\ \text { 6. } & \text { H. M. Butler } \\ 7 . & \text { R. B. Cumming } \\ 8-23 . & \text { C. E. Easterly } \\ 24 . & \text { J. W. Elwood } \\ 25 . & \text { W. Fulkerson } \\ 26 . & \text { W. R. Grimes } \\ 27 . & \text { D. G. Jacobs } \\ 28 . & \text { S. V. Kaye } \\ 29 . & \text { J. F. Land } \\ 30 . & \text { T. W. Oakes } \\ 31 . & \text { O. B. Morgan } \\ 32-4.8 . & \text { J. E. Phillips } \\ 49 . & \text { J. K. Poggenburg }\end{aligned}$

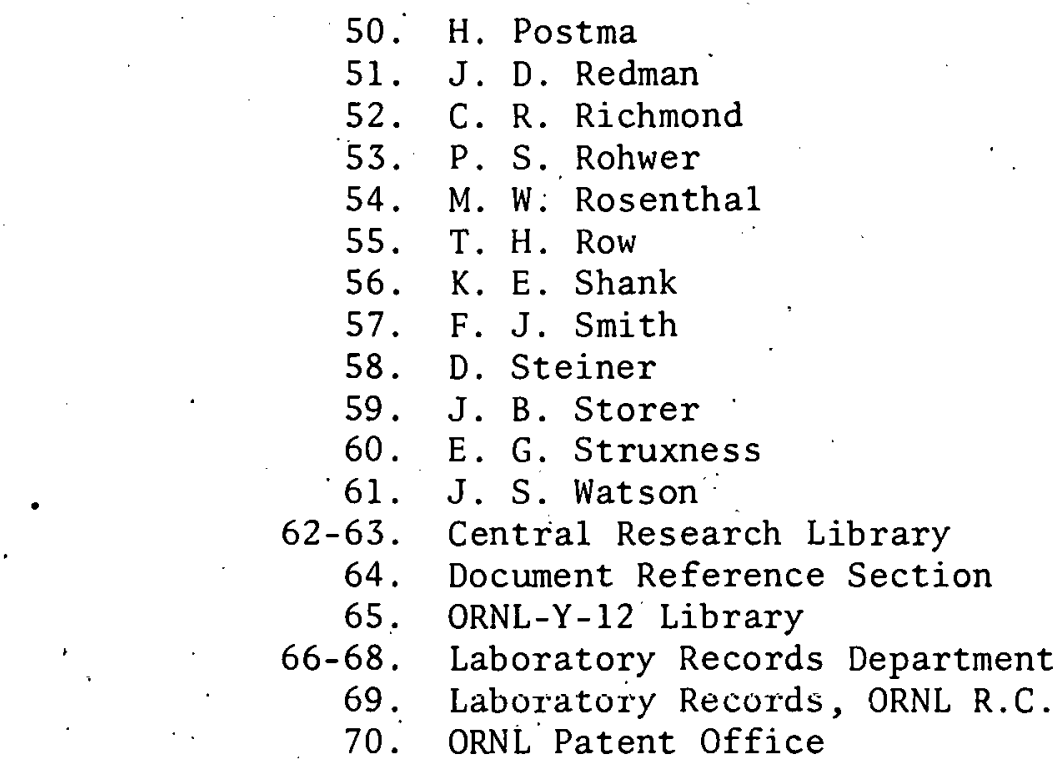

EXTERNAL DISTRIBUTION

71. N. A. Amherd, EPRI, P.0. Box 10412, Palo Alto, CA 94303

72. J. Baublitz, Division of Magnetic Fusion Energy, DOE, Washington, DC 20545

73. R. P. Blaunstein, Division of Technology Overview, DOE, Washington, DC 20545

74. R. L. Butenhoff, Division of Biomedical and Environmental Research, DOE, Washington, DC 20545

75. F. E. Coffman, Division of Magnetic Fusion Energy, DOE, Washington, DC 20545

76. F. Flakus, International Atomic Energy Agency, Kartner Ring 11, P.0. Box 590, A-1011 Vienna, Austria

77. T. R. Galloway, Lawrence Livermore Laboratory, Livermore, California 94550 .

78. A. Goldberg, Division of Technology Overview, DOE, Washington, DC 20545

79. P. Hancox, United Kingdom Atomic Energy Agency, Culham Laboratory, Abingdon, Berkshire, Engl and

80. Hoi-Ying Holman, EPRI, P.0. Box 10412, Palo Nlto, CA 94303

81. F. Hudson, Division of Biomedical and Environmental Research, DOE, Washington, DC 20545

82. F. Hlungate, Battelle Pacific Northwest Laboratories, Richland, Washington 99352

83. A. B. Johnson, Battelle Pacific Northwest Laboratories, Richland, Washington 99352 
84. W. E. Kastenburg, School of Engineering and Applied Science, UCLA, Los Angeles, $\mathrm{Ca} .90024$

85. K. Lind, Ebasco/Grumman Team, Princeton University, Plasma Physics Laboratory, James Forrestal Campus, A-Site, Building 1-0, Princeton, N.J. 08540

86. V. A. Maroni, Argonne National Laboratory, Argonne, I11inois 60439

87. W. D. Patterson, Lawrence Livermore Laboratory, Livermore, California 94550

88. K. Sako, JAERI, Tokai, Japan

89. F. R. Scott, EPRI, 3412 Hillview Ave., Palo Alto, California 94303

90. J. K. Soldat, Battelle Pacific Northwest Laboratories, Richland, Washington 99352

91. J. Swinebroad, Division of Biomedical Environmental Research, DOE, Washington, DC 20545

Y'2. H. J. Willenberg, Battèlle rácific Northwest Laboratories, Rlchland, Washington 9935'

93. R. W. Wood, Division of Biomedical and Environmental Research, DOE, Washington, DC 20545

94. J. R. Young, Battelle Pacific Northwest Laboratories, Richland, Washington 99352

95. Director, Research and Technical Support Division, DOE-ORO

96-229. Given distribution as shown in TID-4500 under UC-20, Magnetic Fusion Energy and UC-20e, Environment and Safety. 